\title{
The Impact of Financial Performance Indicators and Audit Implications on Readability Financial Reports in Companies Listed in the Iranian Capital Market
}

\author{
Yaghoub Hosseinpour \\ Isfahan(khorasgan)Branch,IslamicAzad \\ University,Isfahan,Iran(yhp.hosseinpour@gmail.com) \\ Naser Izadinia * \\ Associate Professor of Accounting, University of Isfahan, Isfahan \\ ,Iran(Corresponding Author),N.Izadinia@ase.ui.ac.ir \\ Hamzeh Mohammadi Khoshoui \\ Assistant Professor of Accounting, Isfahan (Khorasgan) Branch, Islamic \\ Azad University, Isfahan,Iran(mohammadi.khosh@yahoo.com)
}

\begin{abstract}
:
Managers and auditors in the performance and audit process in recent years pay special attention to the way information is presented and the readability of financial reporting and try to manage it. Managers using the hypothesis of management ambiguity seek to obscure and to conceal information through complicating and less transparency in financial reporting. On the other hand, auditors also assess the risk of audit contracts with employers. This study aims to investigate the performance indicators and audit implications on the Linguistic Complexity of Financial Information Disclosure based on Readability in companies listed on the Tehran Stock Exchange. In this study, the return on assets as a performance indicator and the delay of the audit report and changes of the auditor as audit outcomes and to measure readability, the Fog index has been used. Data of 152 companies were analyzed by elimination sampling method for the period 2010 to 2020 . The research method is regression analysis and data panel and GMM approach has been used to test the research models. The results of testing the hypotheses show that the return on assets have a negative and significant effect on the readability of financial statements. In addition, the delay of the auditorchr's report has a positive effect on the

Copyrights:

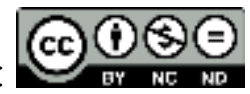

This license only allowing others to download your works and share them with others as long as they credit you, but they can't change them in any way or use them commercial.
\end{abstract}


readability and the auditorchr's changes have a negative and significant effect on the readability of the auditorchr's report.

Keywords: Financial Performance Indicators, Audit Implications, Readability of financial reporting.

\section{Copyrights:}

\section{(c) $(1) \Theta$}

This license only allowing others to download your works and share them with others as long as they credit you, but they can't change them in any way or use them commercial. 


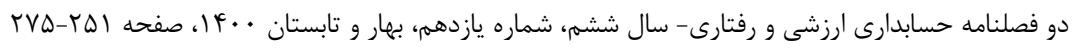

تاثير شاخص هاى عملكرد مالى و ييامدهاى حسابرسى برخوانايى كزارشكرى مالى در شر كتهاى يذير فته شده دربازار سر مايه ايران

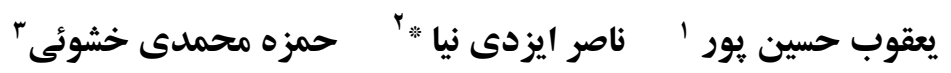

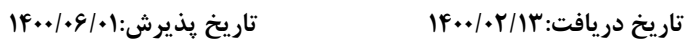

\begin{abstract}
جكيده
مديران و حسابرسان در فرايند عملكرد و حسابرسى در سالهاى اخير به نحوه ارائه اطلاعات و

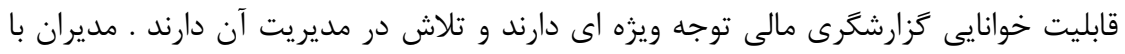

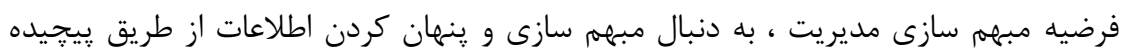

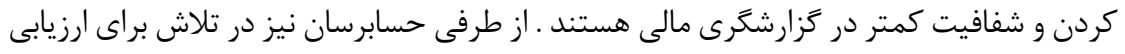

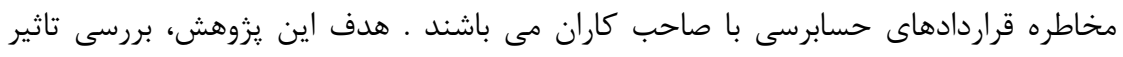

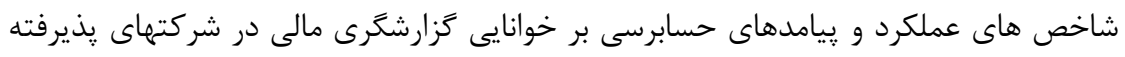

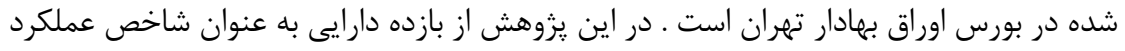

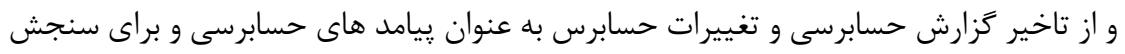

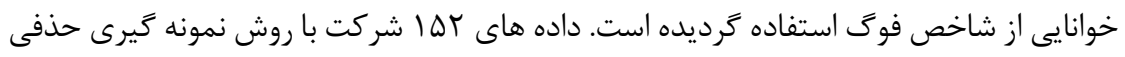

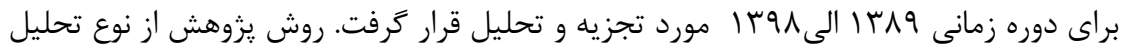

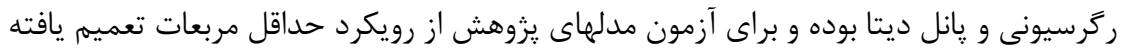

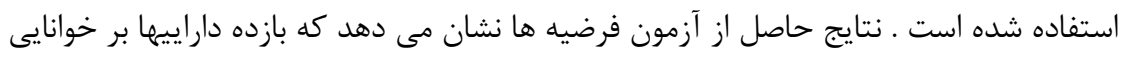

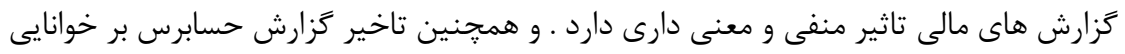

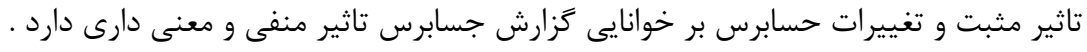

$$
\text { وازه هاى كليدى: شاخص عملكرد مالى، پيامد حسابرسى، خوانايى گزارشكرى مالى }
$$
\end{abstract}

'دانشجوى دكتراى حسابدارى ، دانشخاه آزاد اسلامى ، واحد اصفهان (خوراسكان) ، اصفهان ، ايران

(yhp.hosseinpour@gmail.com)

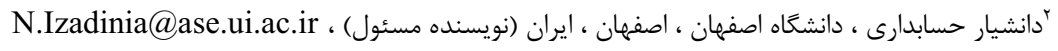

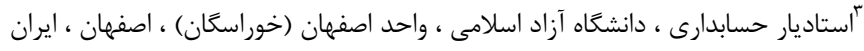
(mohammadi.khosh@yahoo.com) 


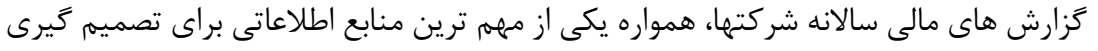

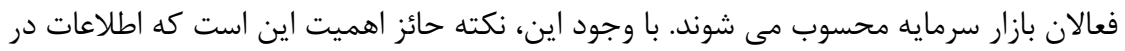
صورتى براى تصميم كيرى ها مفيد خواهد بود كه از نظر استفاده كنند

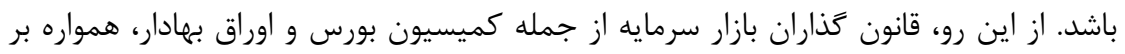

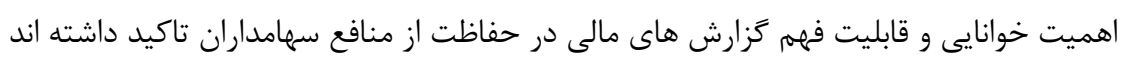

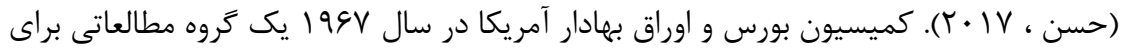

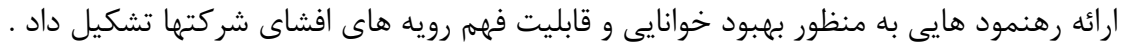

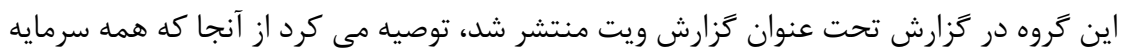

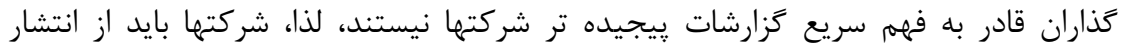

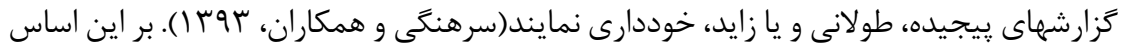

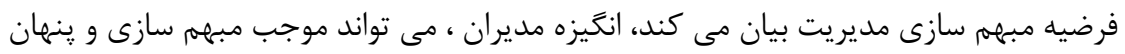

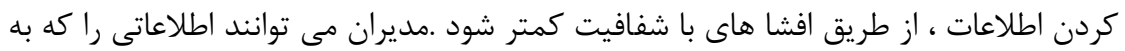

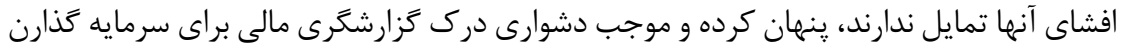

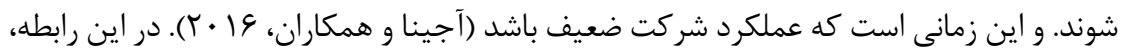

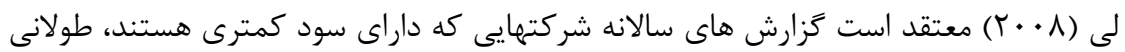
و ويجيده تر و غير شفاف تر از ساير شركتها است.

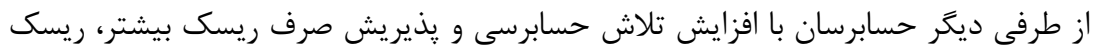

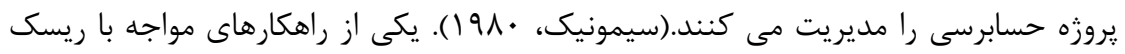

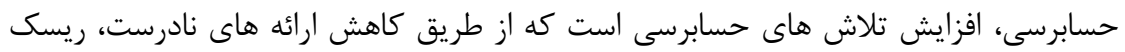

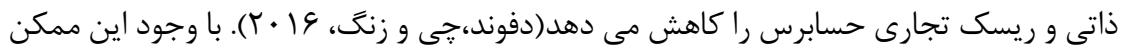

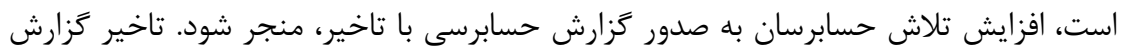

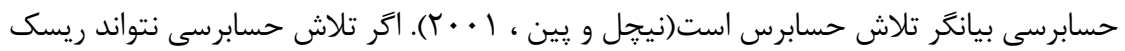

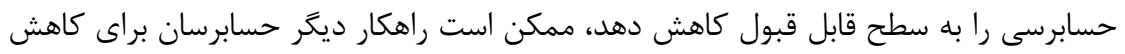

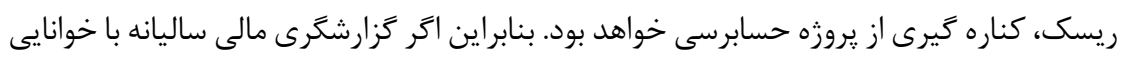

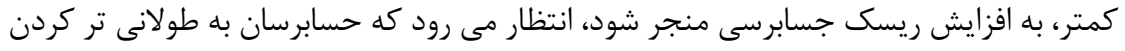

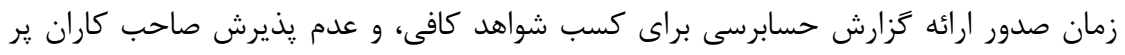

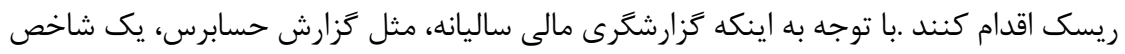

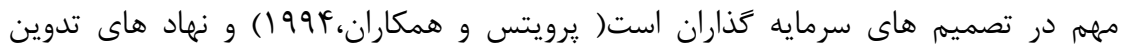

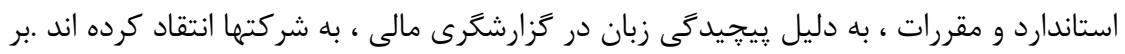


اساس شواهد ارائه شده از يزوهش هاى يِيشين، اين يِيجيدَى براى سرمايه كذاران ير هزينه

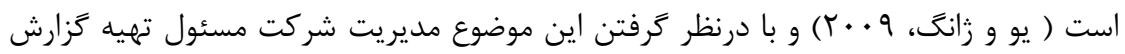

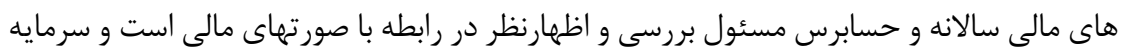
كذاران بر گزارش حسابرس اتكا مى كنند.

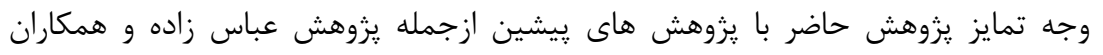

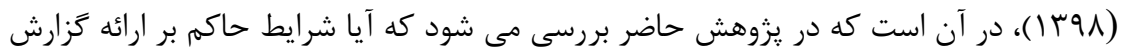

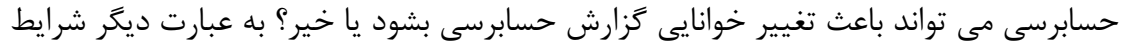

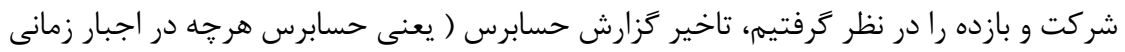

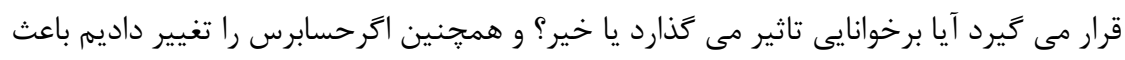

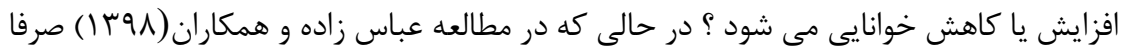

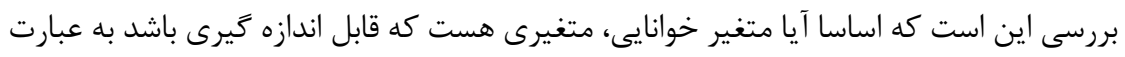

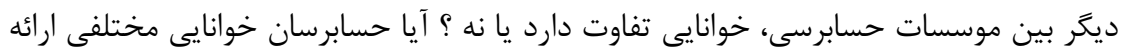

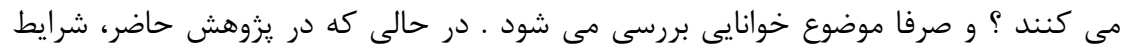

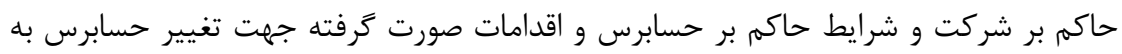
جهت حصول خوانايى بيشتر و كمتر انجام مى شو شود

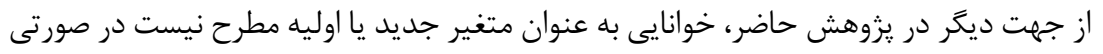

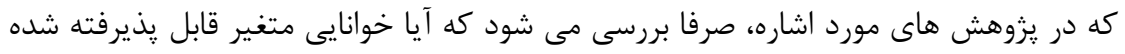

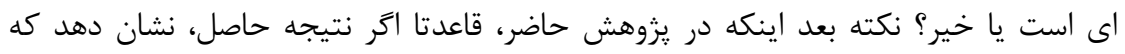

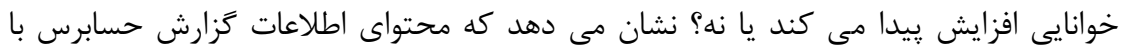

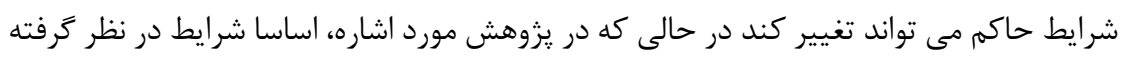

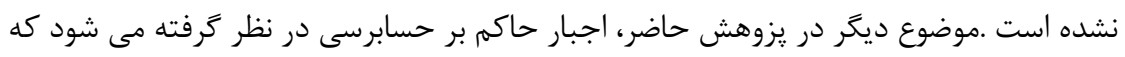

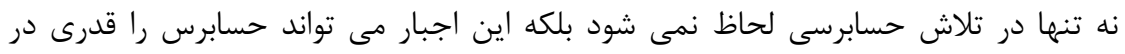

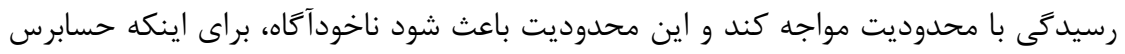

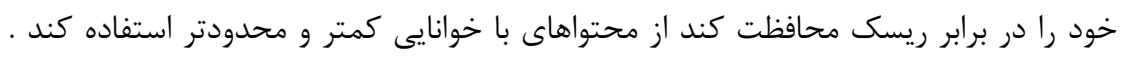

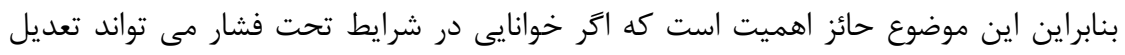

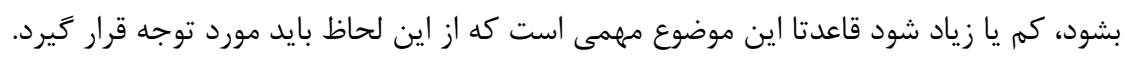

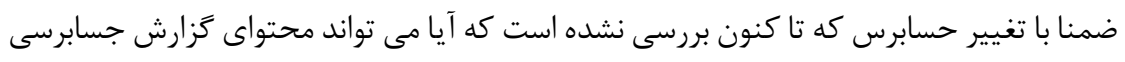

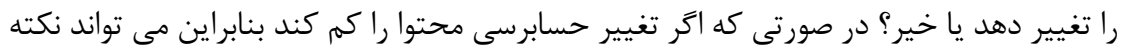


در اين يزوهش با استفاده از مبانى نظرى متغيرهاى يزوهش و با استفاده از يافته هاى يزوهش

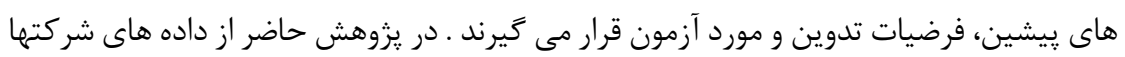

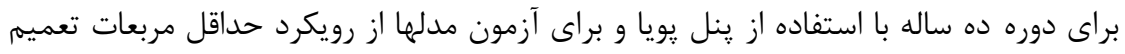
يافته براى حل مشكلات مربوط به خود همبستگى و ناهمكنى استفاده كرديده، تا بتوان يافته هاى قابل اتكا و قابل تعميم بدست آورد.

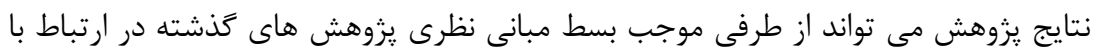

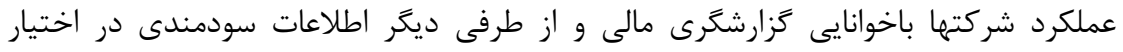

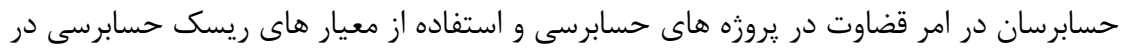

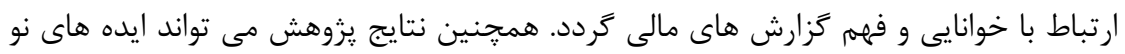

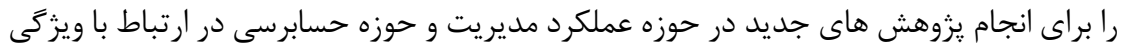
هاى خوانايى ززارشكرى مالى بيشنهاد نمايد.

\section{r-مبانى نظرى و يِيشينه پيزوهش}

فهميدن يك متن عوامل مختلفى را شامل مى شود، به ويزه عوامل مرتبط با متن، خواننده و

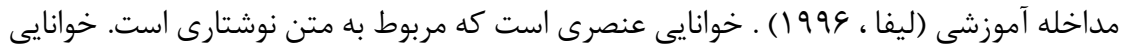

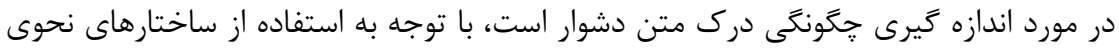

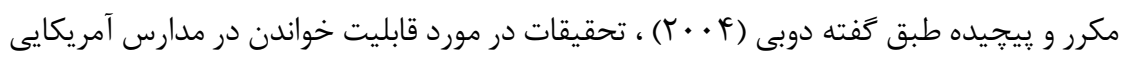

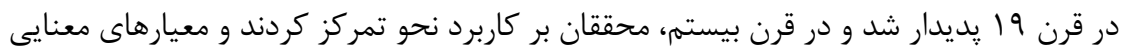

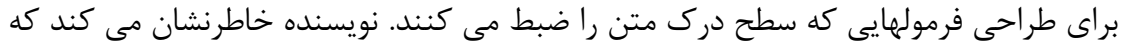

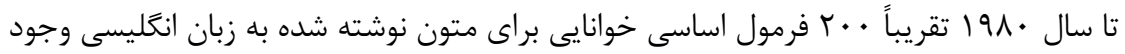

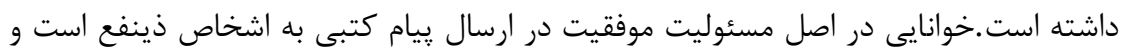

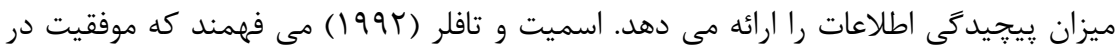

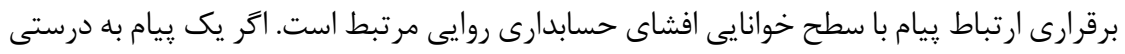

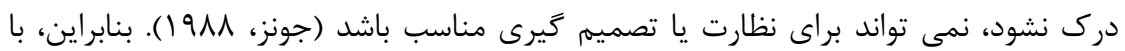

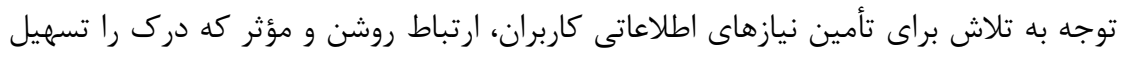

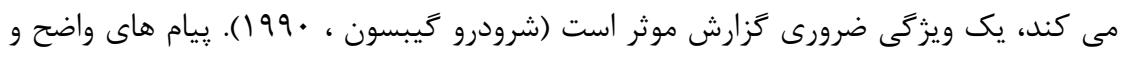

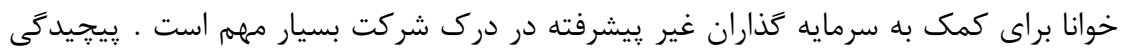

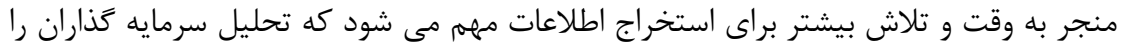

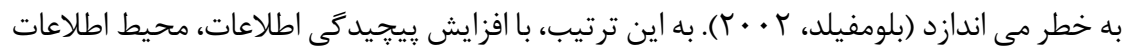


مانع مى شود. اگرجه مرتبط است، اين موضوع در تحقيقات دانشگاهى اندكى مورد بحث قرار

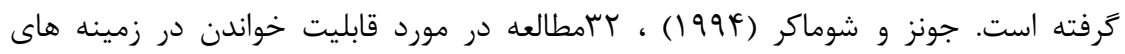

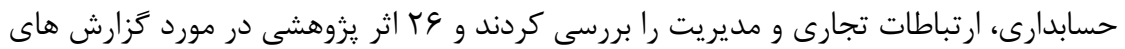

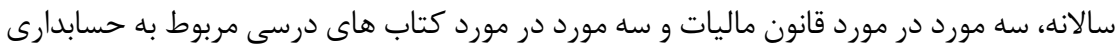

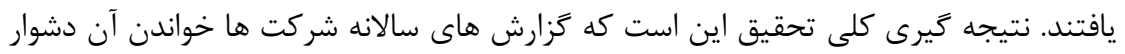

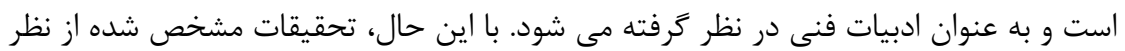

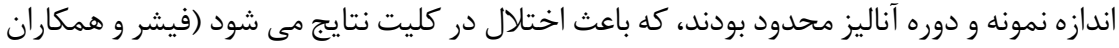

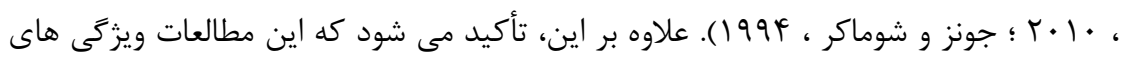

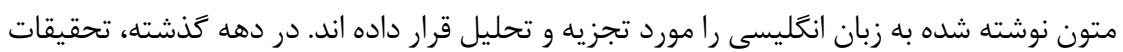

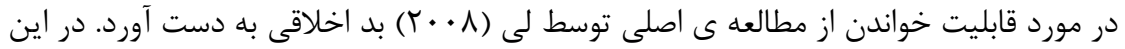

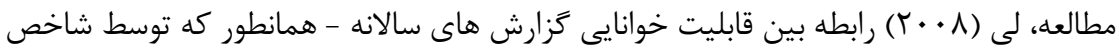

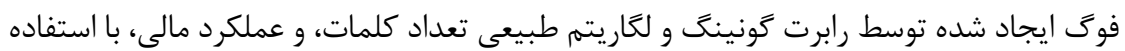

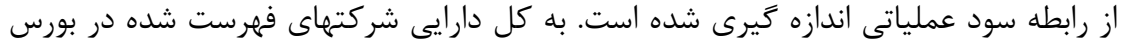

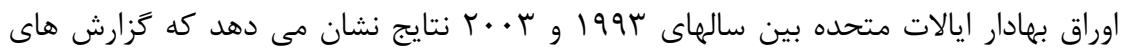

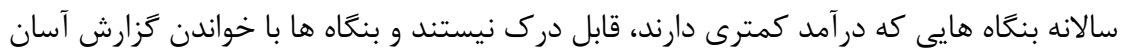

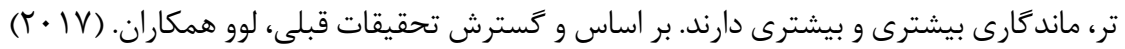

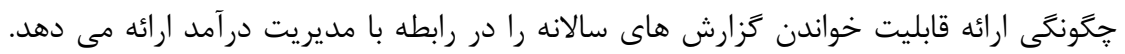

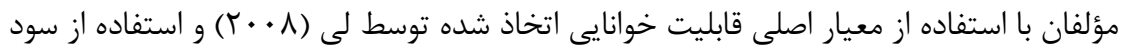

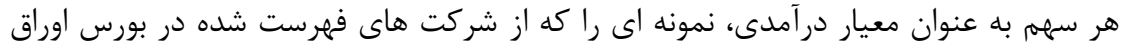

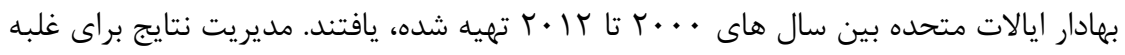

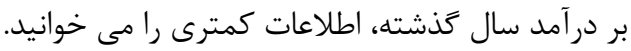

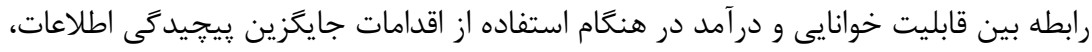

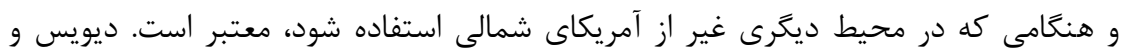

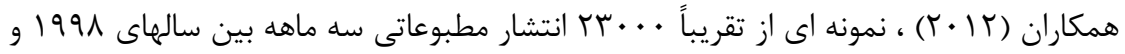

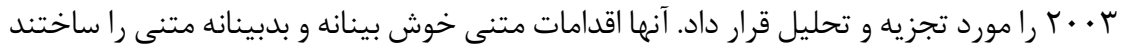

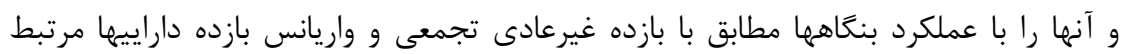

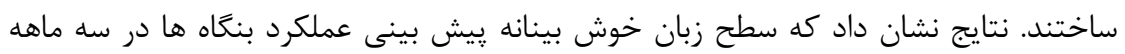

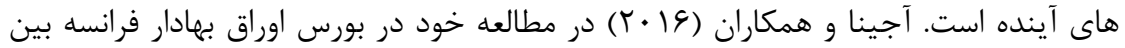

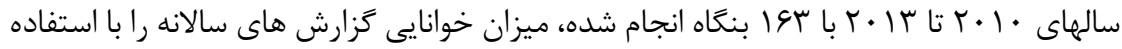

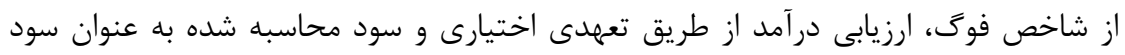


خالص مقياس شده توسط كل دارايى ها ارزيابى كرده است. يافته ها نشان مى دهد شركت هايى

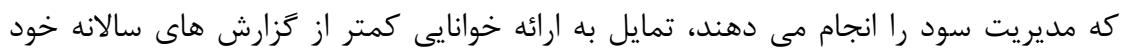

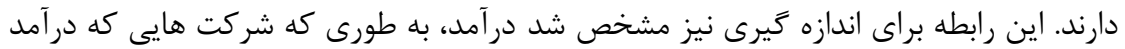

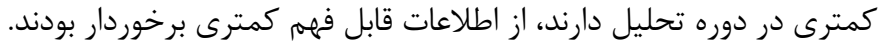

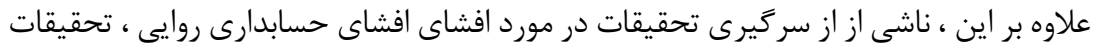

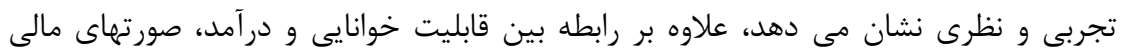

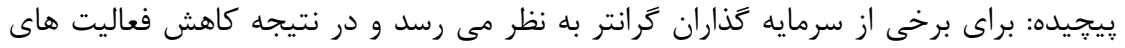

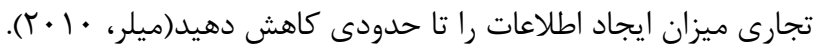

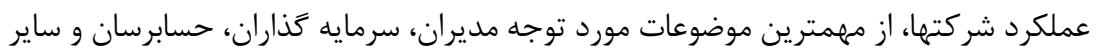

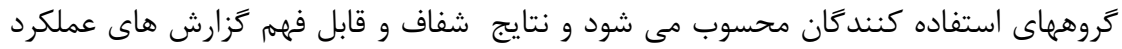

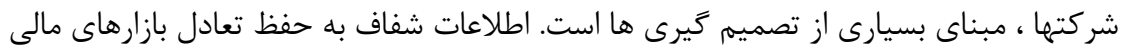

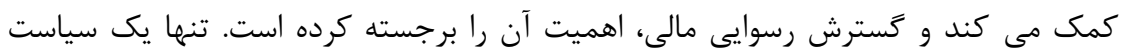

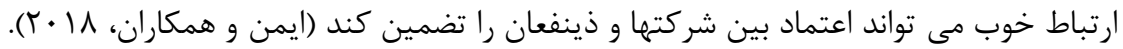

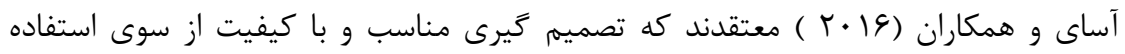

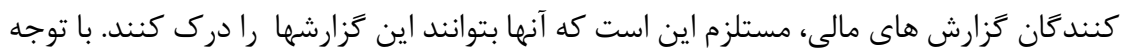

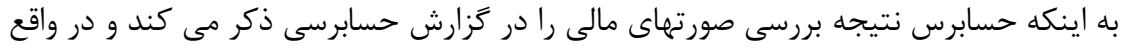
كزارش حسابرسى راه ارتباطى بين حسابرس و عملكرد مديران شركت و واستفاده كنندكان است،

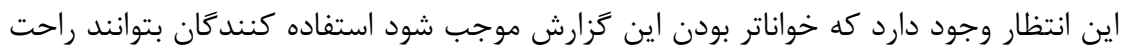

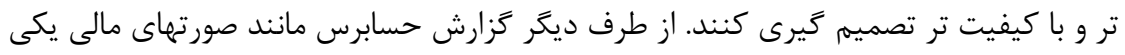

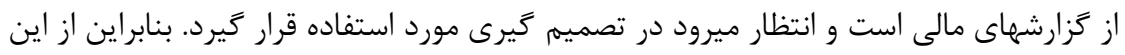

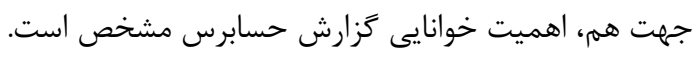

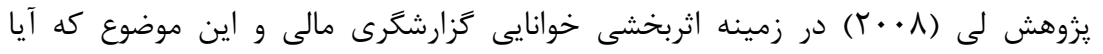

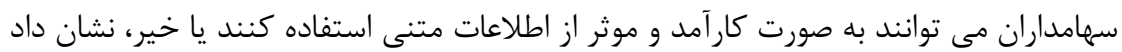

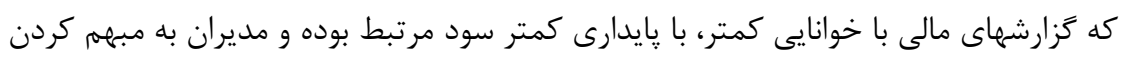

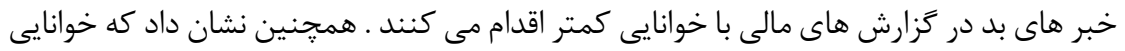

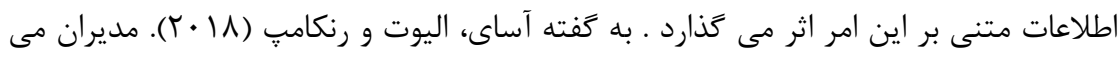

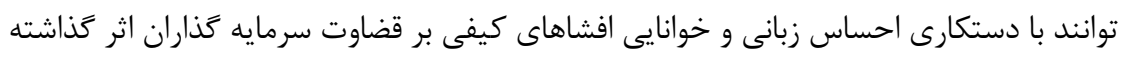

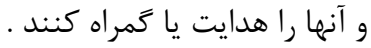

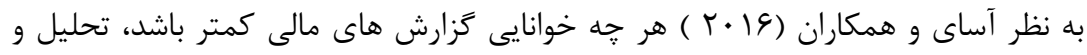

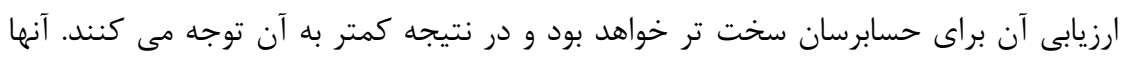


دريافتند كه اعتماد حسابرسان به اطلاعات خواناتر، بيشتر است و منابع اطلاعاتى خارج از شركت

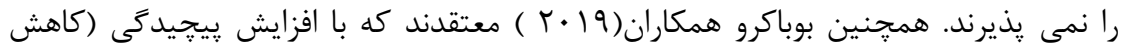

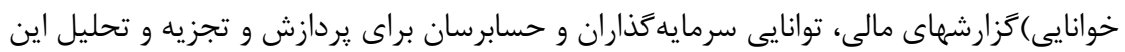

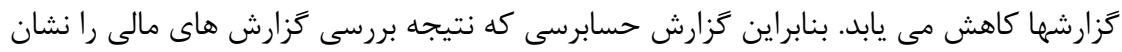

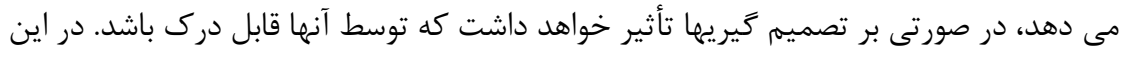

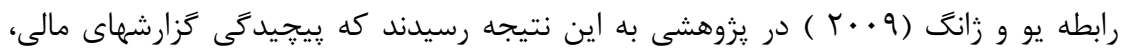

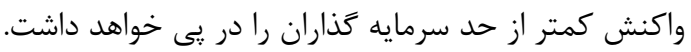

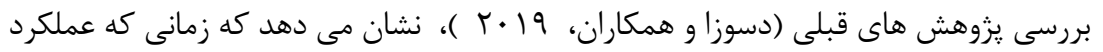

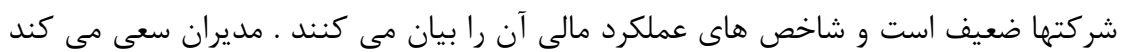

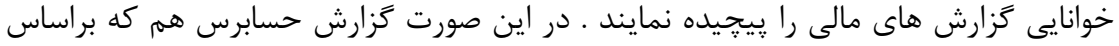

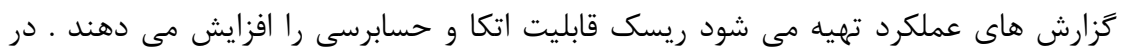

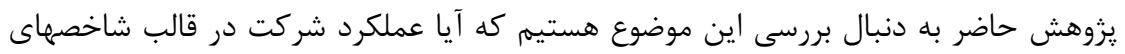

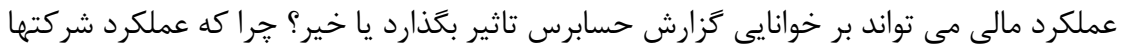

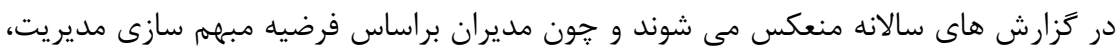

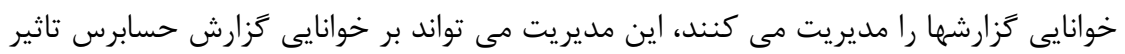

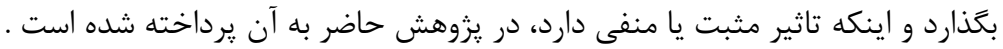

\section{خوانايى تزارش حسابرس و بِيامدهاى حسابرسى 1- إخير كزارش حسابرسى}

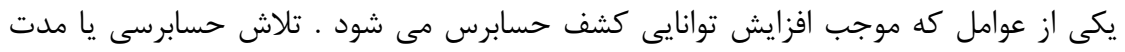

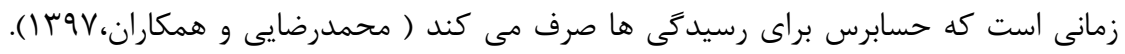

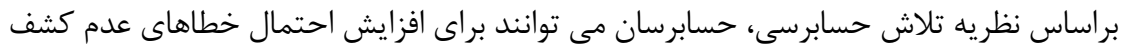

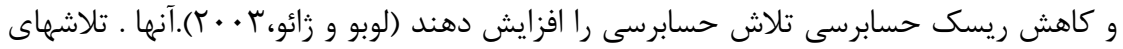

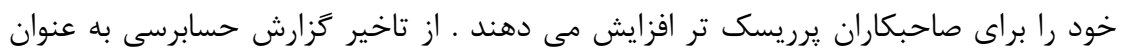

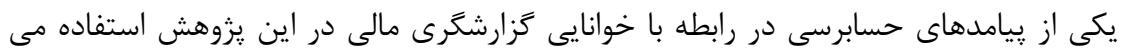

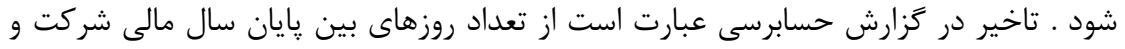

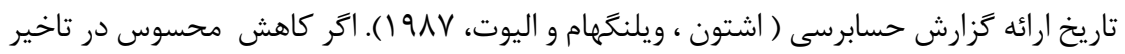

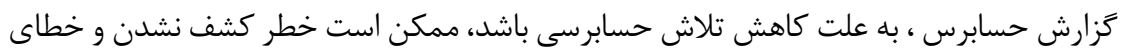

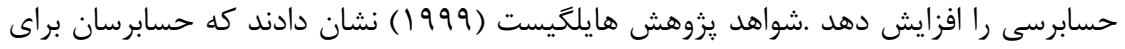

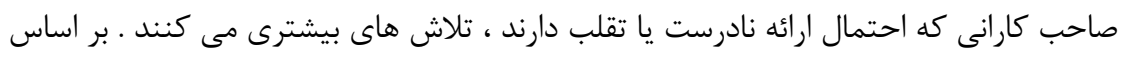


يافته هاى يزوهش رضائى و صفرى كرايلى (ITYV) ، خوانايى گزارشكرى مالى، احتمال وقوع

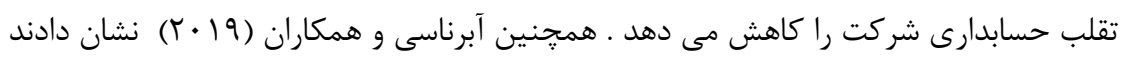

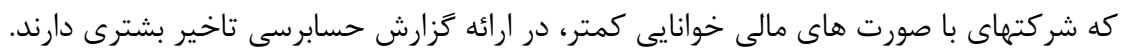

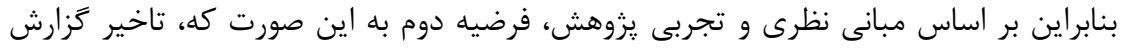

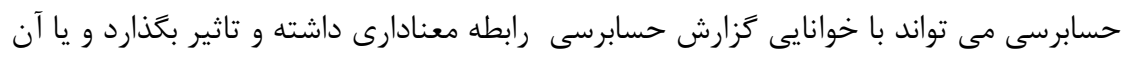
را تعديل كند. تدوين كرده است. r-تغييرات حسابرس

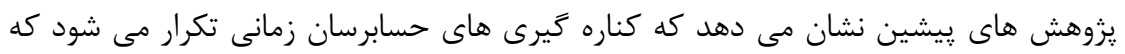

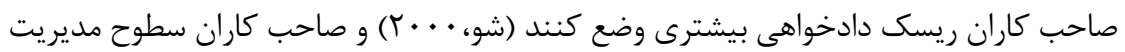

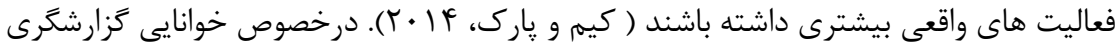

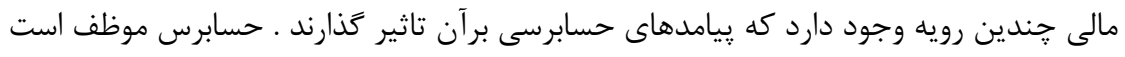

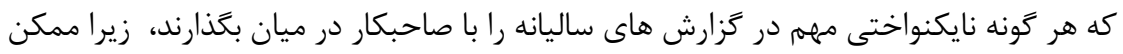

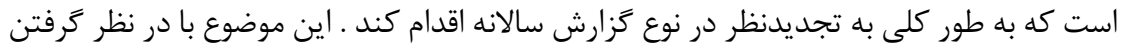

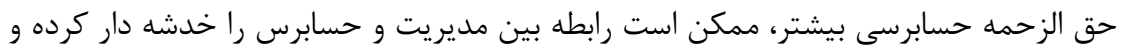

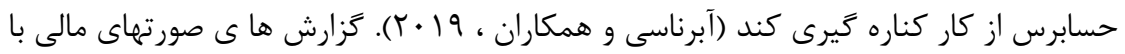

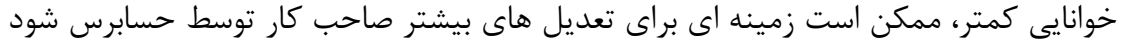

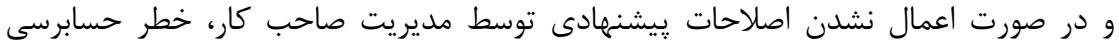

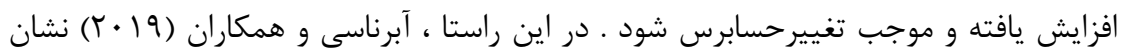

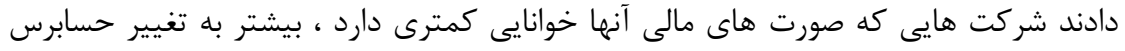

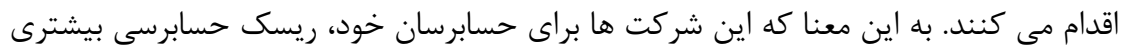

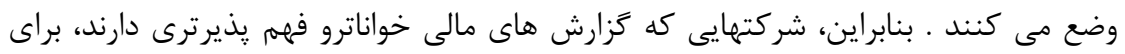
حسابرسان خود ريسك كمترى اعمال مى كنند و انتظار مى رود كه تغيير حسابرس كمترى

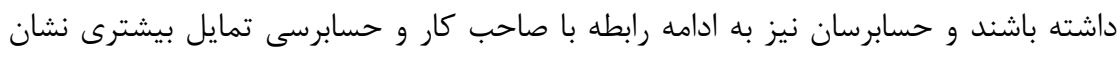

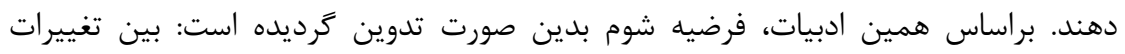

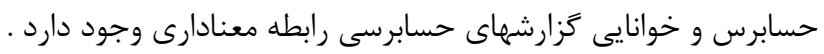

يزوهش هايى در حوزه خوانايى كزارشكرى مالى در داخل وخارج كشور صورت كرفته است كه

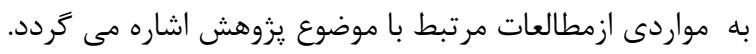

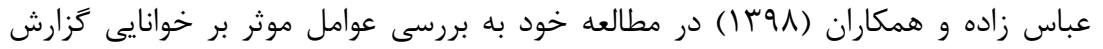

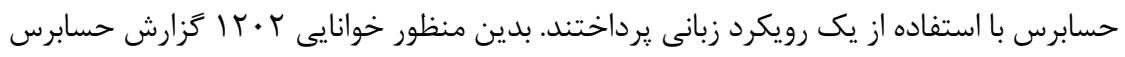




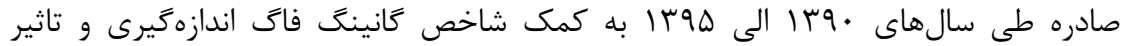

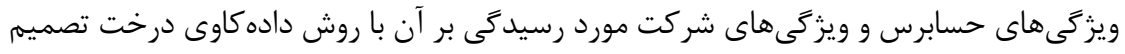

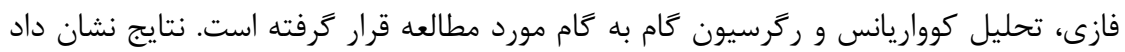

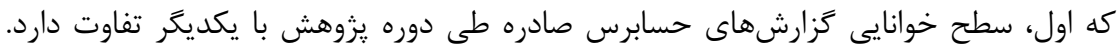
دوم، خوانايى گزارشهاى حسابرس تحت تاثير ويزگ

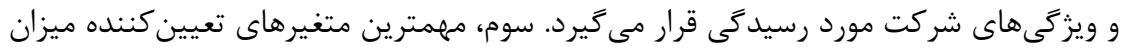
خوانايى تزارش حسابرس به ترتيب اهميت عبارتند از: اندازه موسسه حسابرسى (تاثير منفى)،

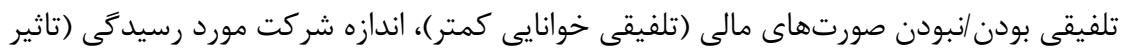

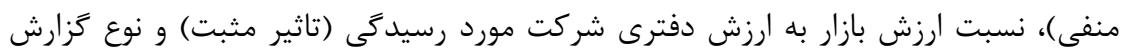

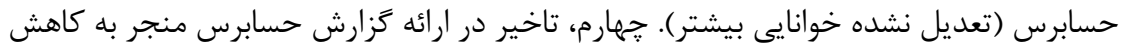
خوانايى آن مى خردد.

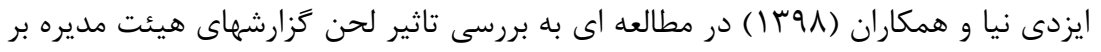

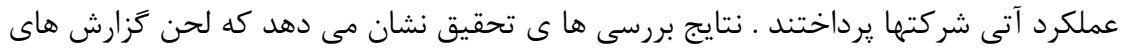

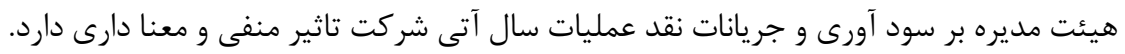

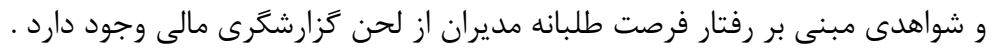

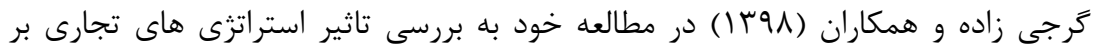

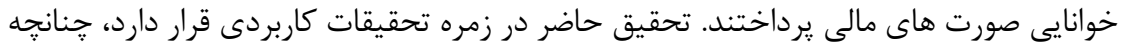

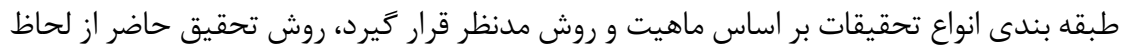
ماهيت در زمره تحقيقات توصيفى قرار داشته و از نظر روش نيز در دسته تحقيقات همبستكى داهي

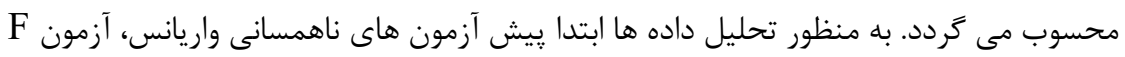

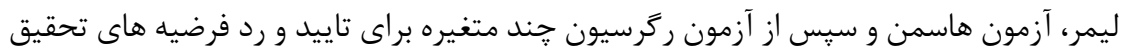

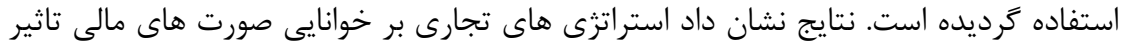
كذارند.

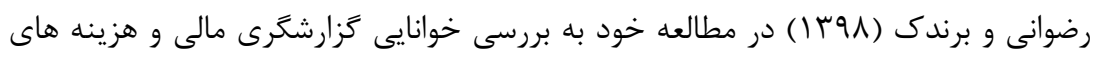

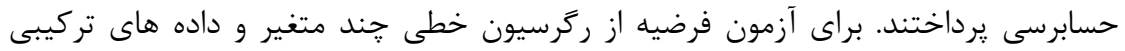

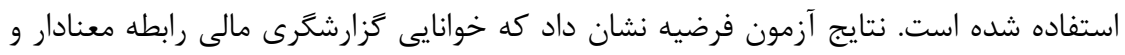

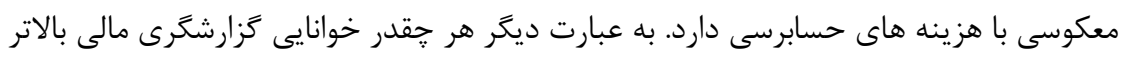

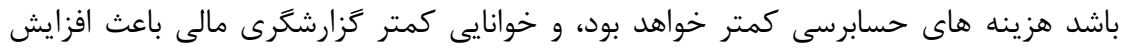

$$
\text { هزينه حسابرسى مى كردد. }
$$




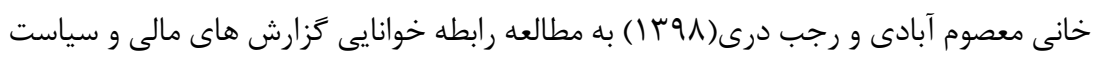

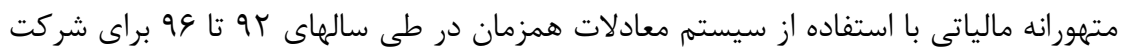

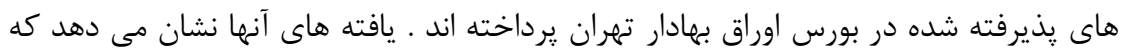

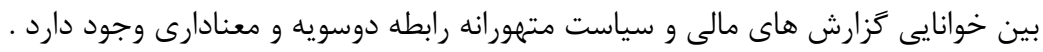

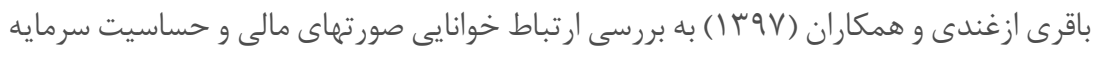

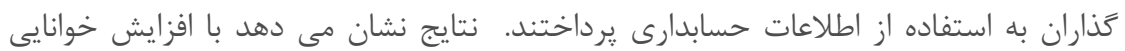

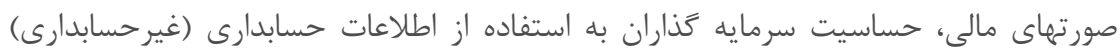

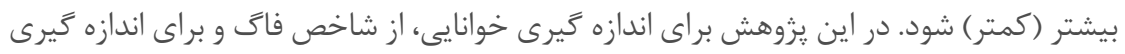

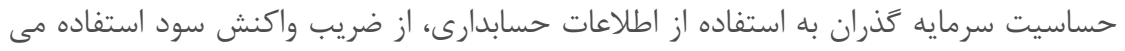

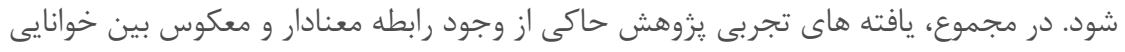

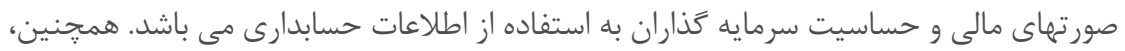

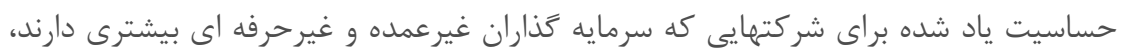

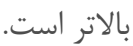

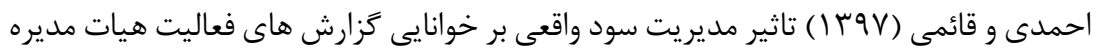

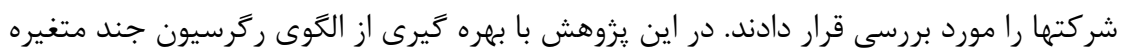

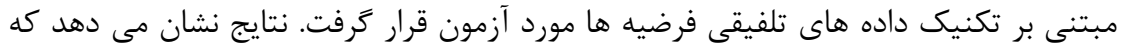

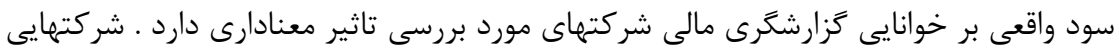

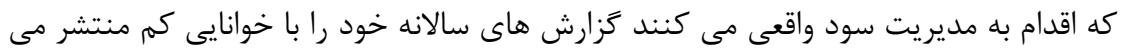

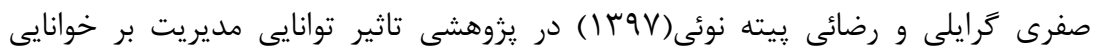

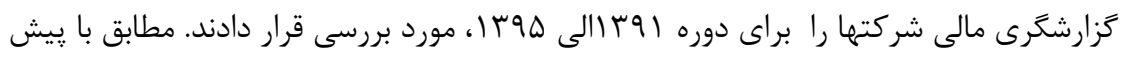

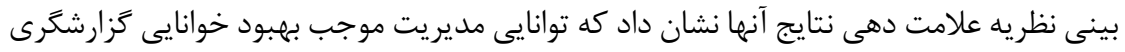

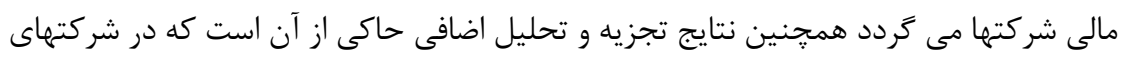

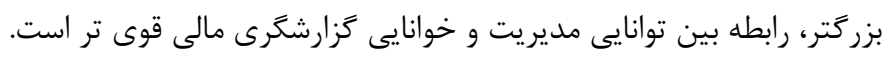

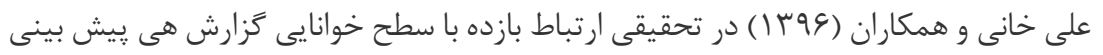

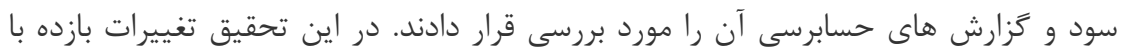

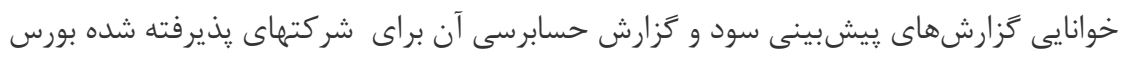

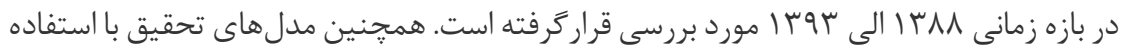

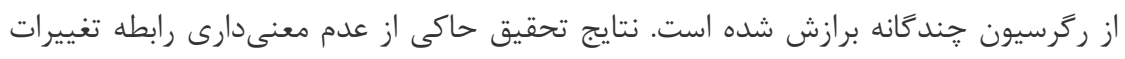

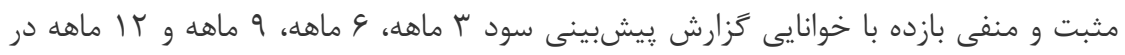


روشهاى فلش و كانينًَ مىباشد. همجنين يافتهها حاكى از عدم معنى دارى رابطه بين تغييرات

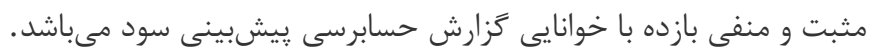

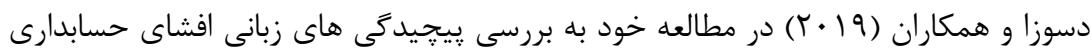

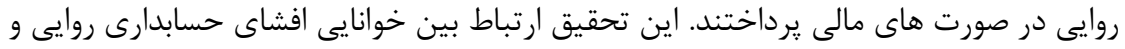

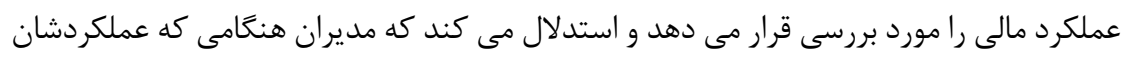

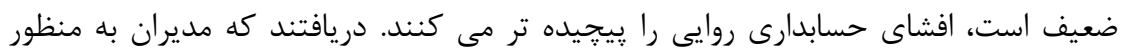

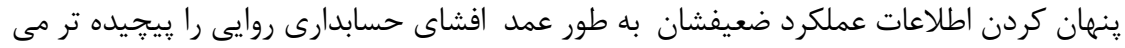

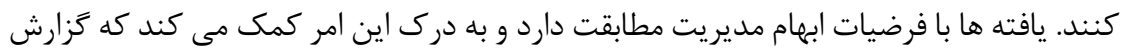

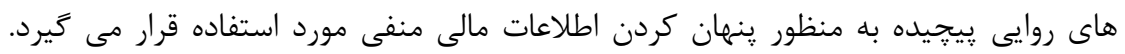

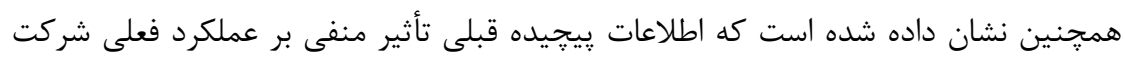

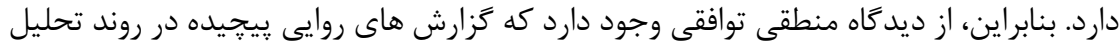
ير هزينه و كم تاثير هستند. آبرناسى و همكاران (1)

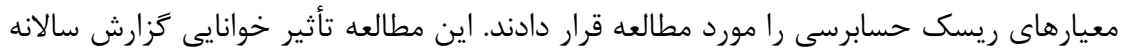

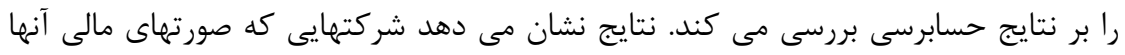

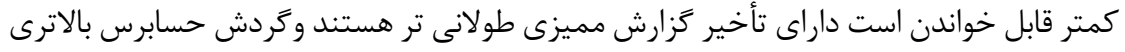

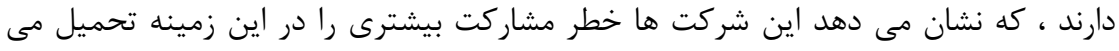

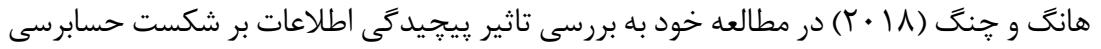

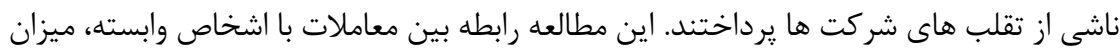

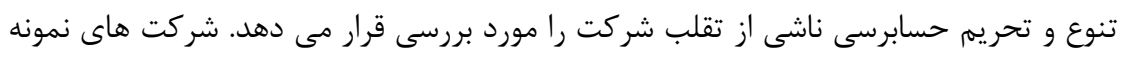

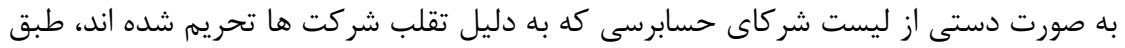

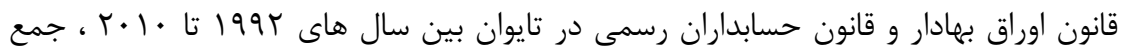

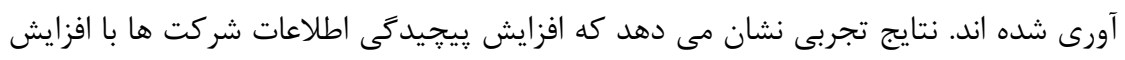

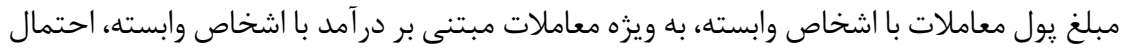

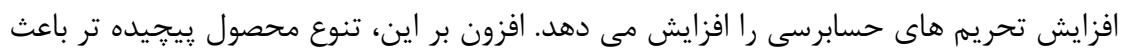

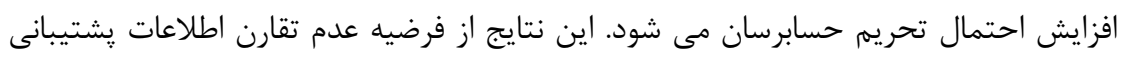

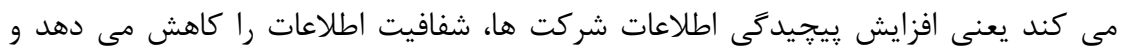

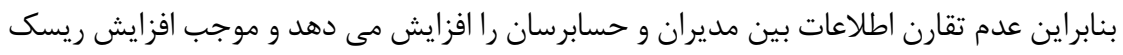


حسابرسى مى شود. اين تحقيقات نشان مى دهد كه حسابرسان زمانى كه شركت داراى معاملات

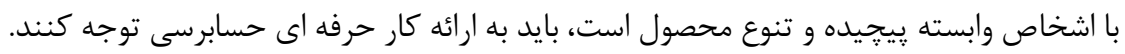

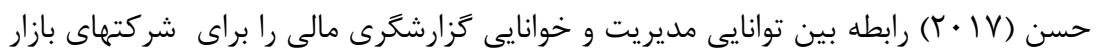

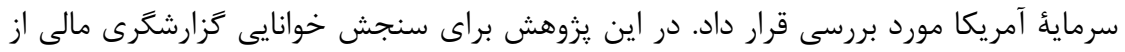

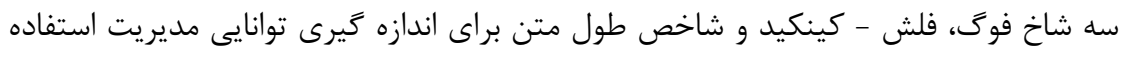

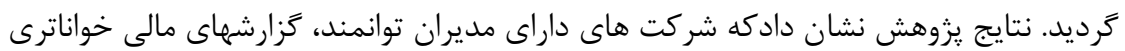
منتشر مى كنند.

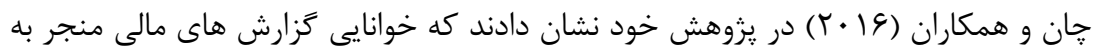

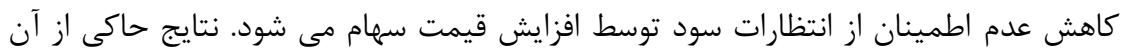

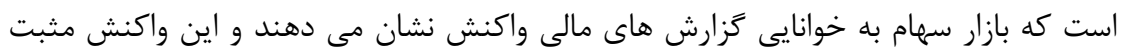

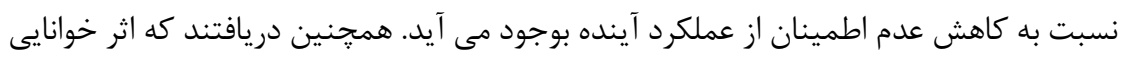

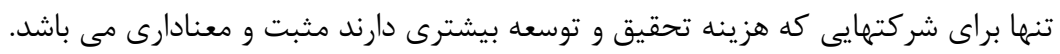

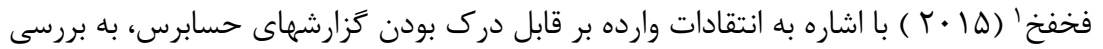

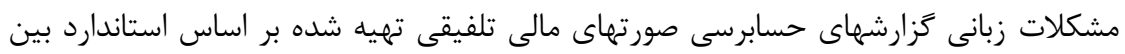

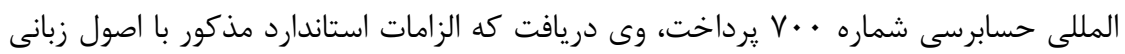

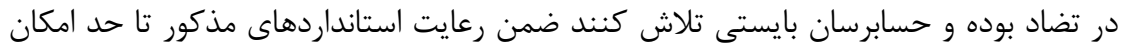
خوانايى كزارش هاى خود را بهينه سازى نمايند.

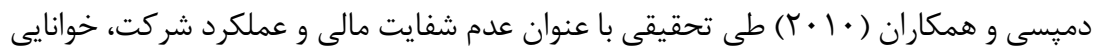

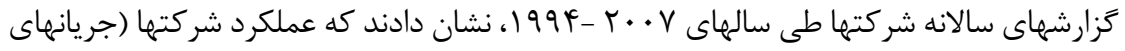

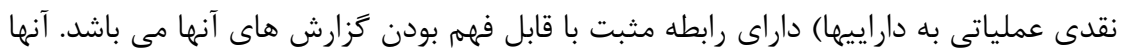

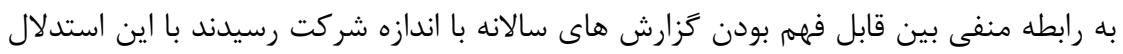

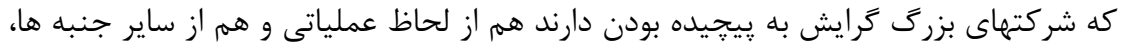

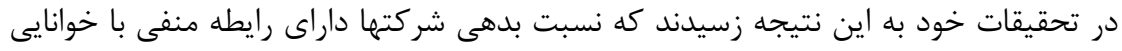
كزارش ها دارد.

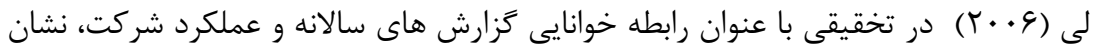

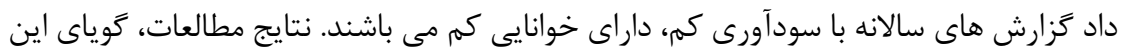

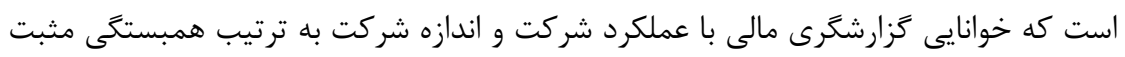

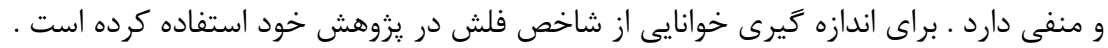

${ }^{1}$ Fakhfakh 
يوند (1911) كزارش حسابرس را ابزارى براى انتقال مفاهيم از حسابرسان به استفاده كنند أنان

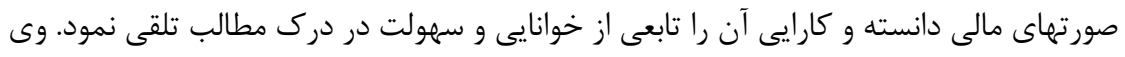

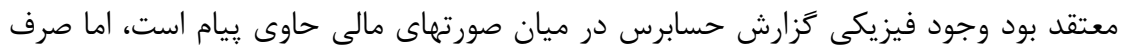

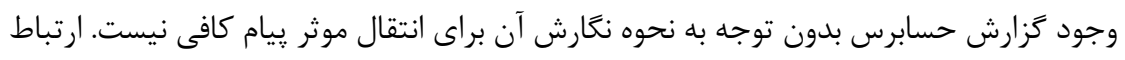

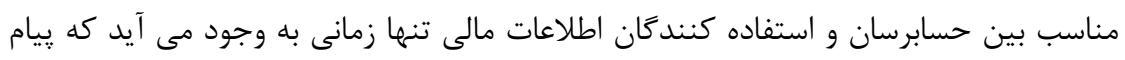

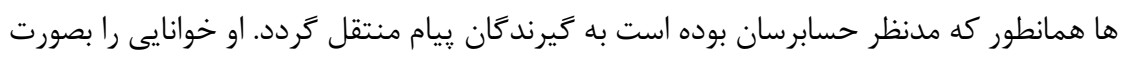

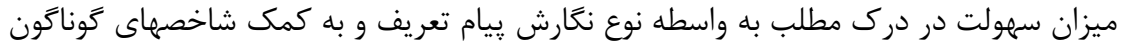

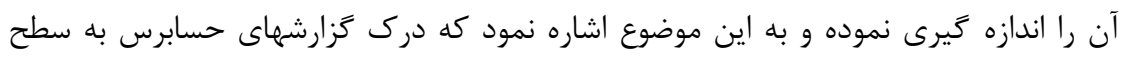

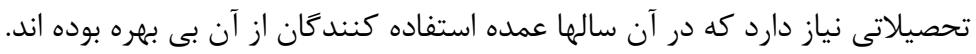

\section{r-فرضيه هاى يزورهش}

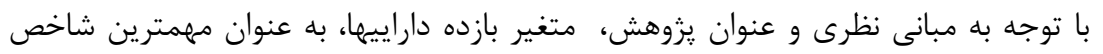

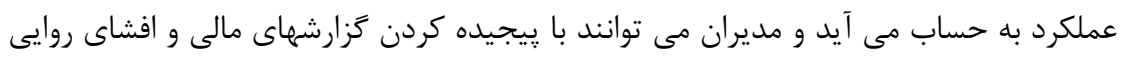

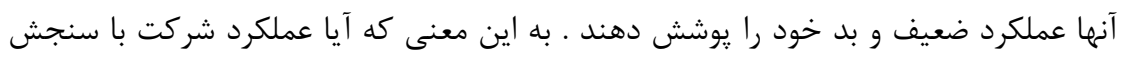

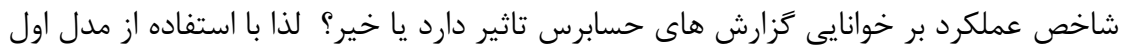

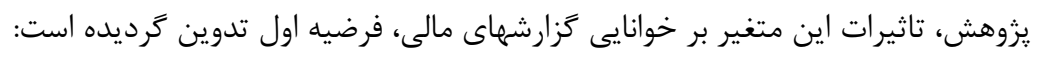

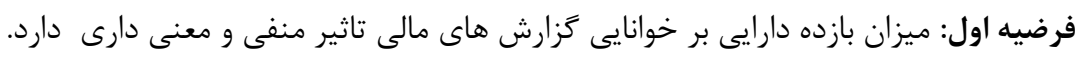

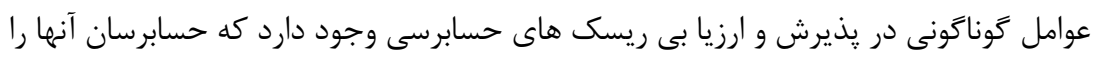

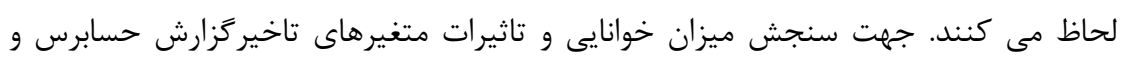

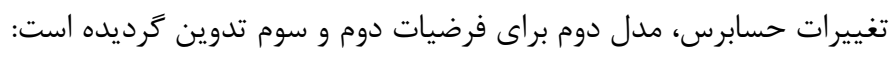

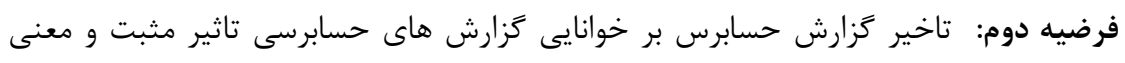
دارى دارد. فرضيه سوم : تغييرات حسابرس بر خوانايى كزارش هاى حسابرسى تاثير منفى و معنى دارى

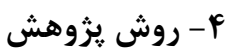

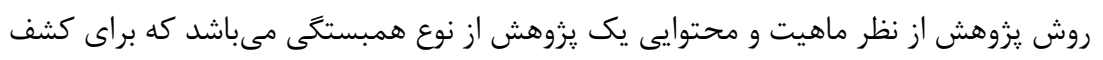

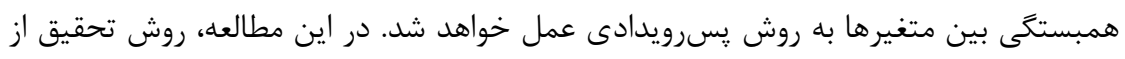

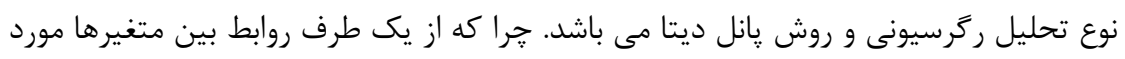

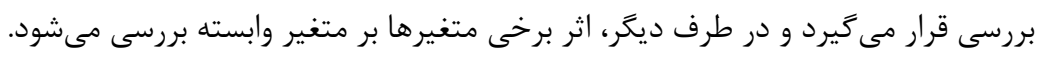


در اين تحقيق با توجه به جامعه آمارى در نظر كرفته شده (شركتهاى موجود در بورس اورد اوراق

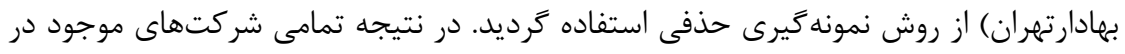

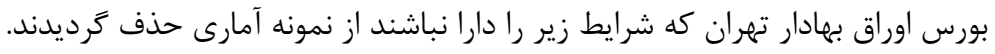
- صورتهاى مالى اساسى آنها براى سال هاى

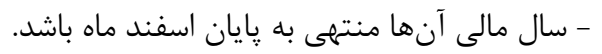

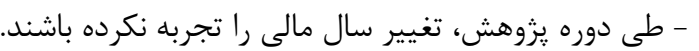

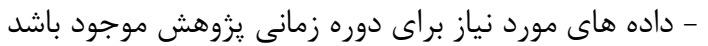

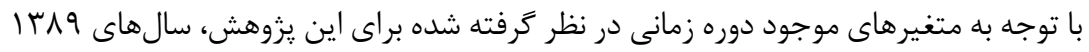

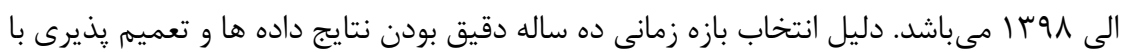

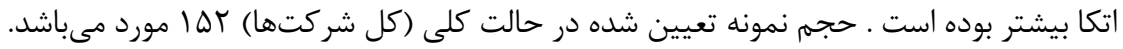

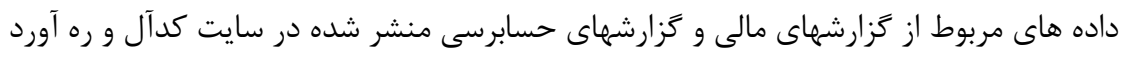

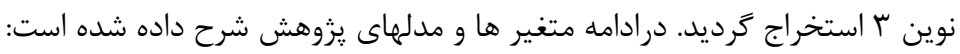

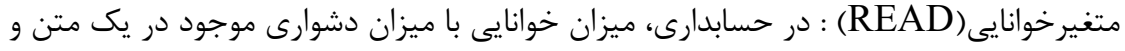

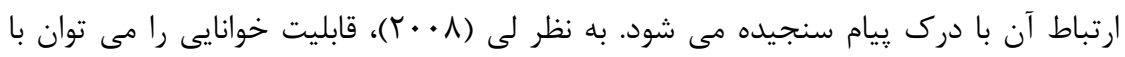

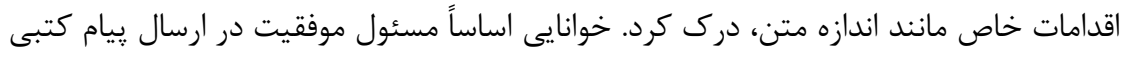

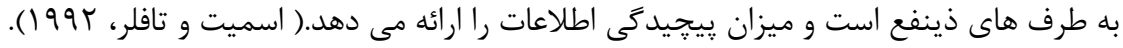

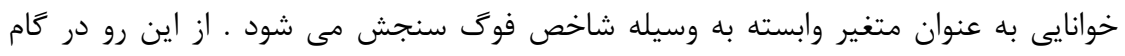
نخست، فايل متنى كزارش هاى حسابرسى مربوط به سال هاى و

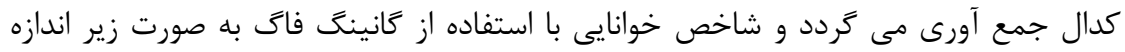

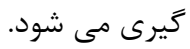

$$
\begin{aligned}
& \text { فرمول شماره (1): }
\end{aligned}
$$

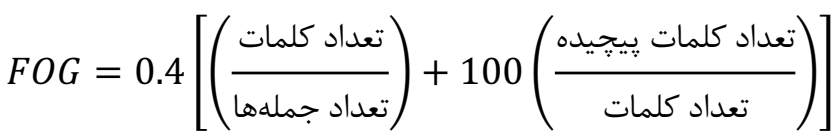

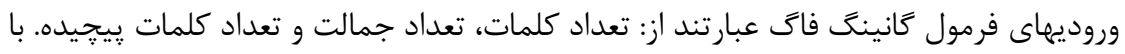

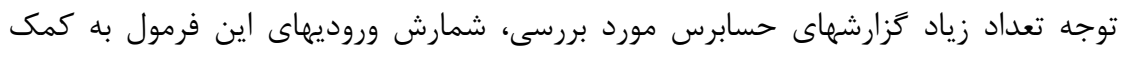

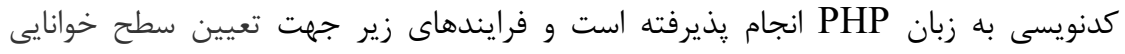
كزارشهاى مالى در شاخص فوق بهترتيب زيرصورت ترفته است: 
() انتخاب يك نمونهُ يكصدكلمهاى از ابتدا، يك نمونهُ يكصد كلمهاى از وسط و يك نمونهٔ

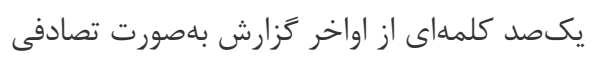
r r شمارش تعداد جمله باى هر يك از نمونهها

r) مشخص كردن متوسط طول جملات ازطريق تقسيم تعداد كلمات به تعداد جملههاى كامل

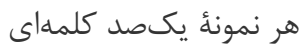

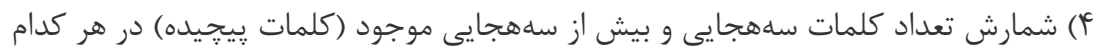

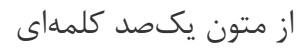

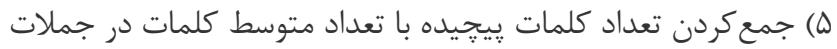

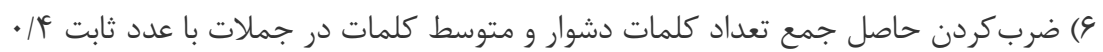

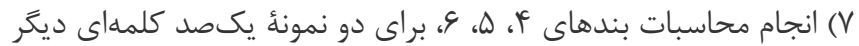

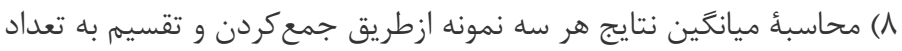

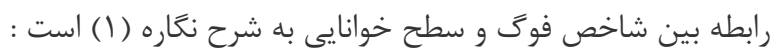

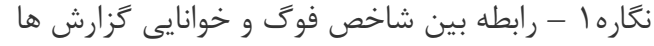

\begin{tabular}{|c|c|c|c|c|c|}
\hline $1 \cdot-\lambda$ & $\mid r-1 \cdot$ & $\mid f-1 T$ & $\left.|\Lambda-|\right|^{k}$ & بالاتر از 11 & شاخص فوى \\
\hline |آسان & قابل قبول & |مناسب & سخت & |ֶيجيده & خوانايى \\
\hline
\end{tabular}

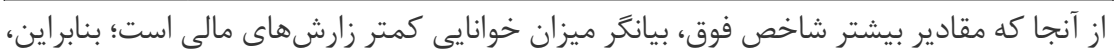

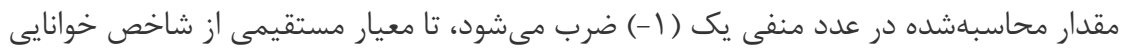
متزارشَّى مالى بهدست آيد.

بازده داراييها(ROA) : بازده كل دارايى هاى يك شركت به عنوان نتيجه فعاليتها و كارايى

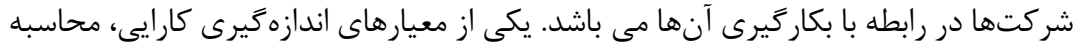

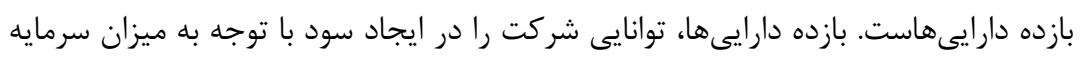

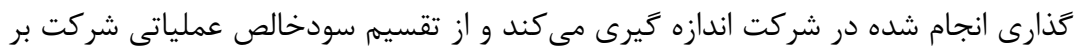

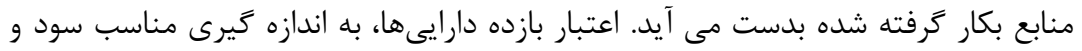

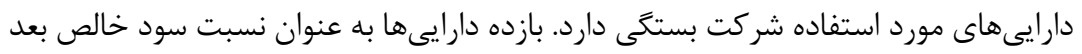

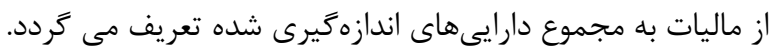

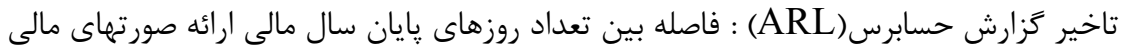

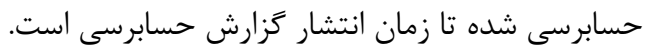


تغييرات حسابرس: (AC)تعدادكردش حسابرس در طول دوره حسابرسى صورتهاى مالى شركتها

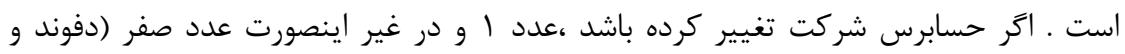

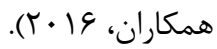
متغير هاى كنترلى

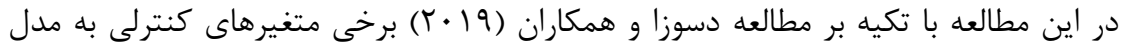
تحقيق اضافه مى شود. اندازه شركت(SIZE): اندازه شركت ممكن است در صورت هافى مالى آنها تأثير بكذارد و آنها را

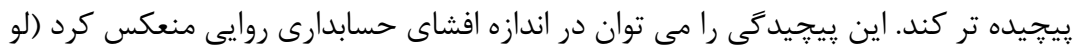

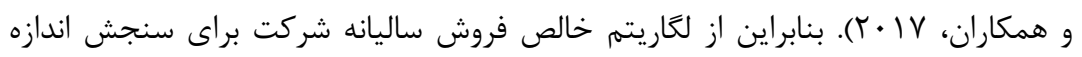
استفاده مى شود. عمر شركت(AGE): در رابطه با سن شركت انتظار مى رود كه شركتهاى با قدمت بيشتر، كزارش

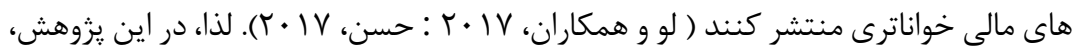

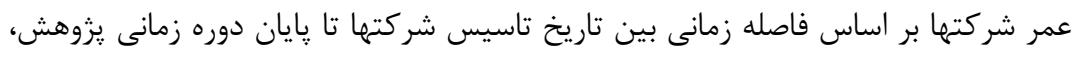
در نظر كرفته شده است. لكاريتم طبيعى تعداد سال هاى فعاليت شركت از مان مان تاسيس.

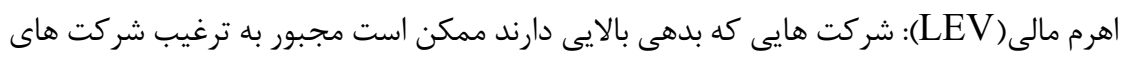

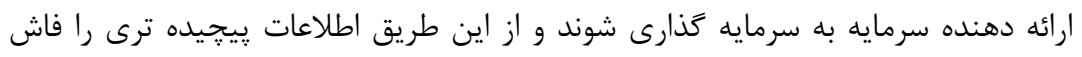

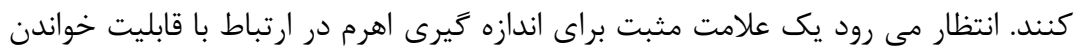

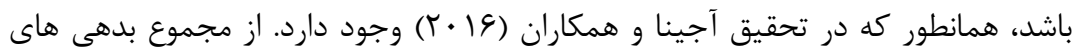
جارى و غيرجارى به كل دارايى به عنوان معيار اهرم استفاده مي شئ شود.

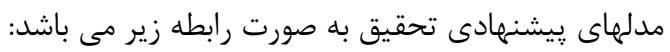

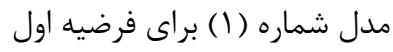
READABILITY $=\beta_{0}+\beta_{1} R O A_{i t}+\beta_{4} S I Z E_{i t}+\beta_{5} A G E_{i t}+\beta_{6} L E V_{i t}+\varepsilon_{i t}$ مدل شماره (T) براى فرضيه هاى دوم و سوم READABILITY $=\beta_{0}+\beta_{1} \mathrm{ARL}_{i t}+\beta_{2} \mathrm{AC}_{i t}+\beta_{3}$ SIZE $_{i t}+\beta_{4} A G E_{i t}+\beta_{5} L E V_{i t}+\varepsilon_{i t}$

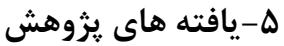

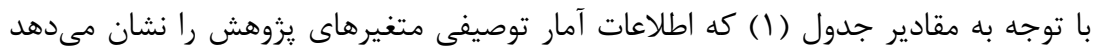

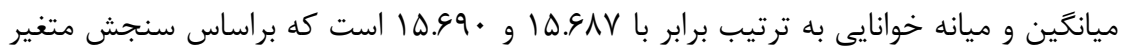

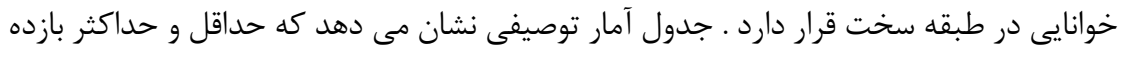

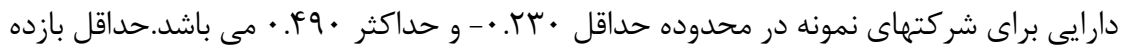


دارايى ها منفى است اين عدد به اين مفهوم است كه در برخى از مشاهدات، شركتها داراى زيان

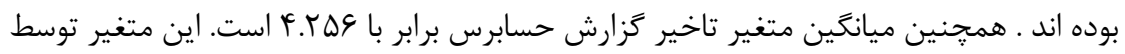

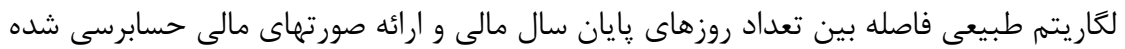

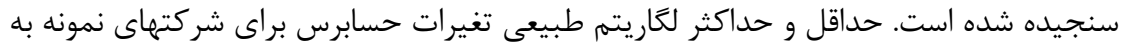

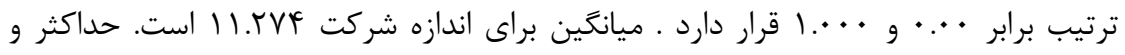

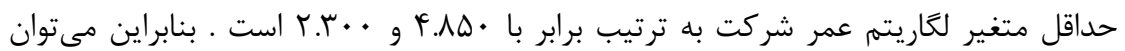

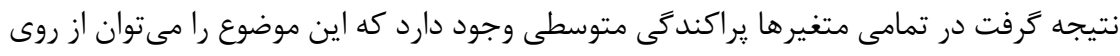

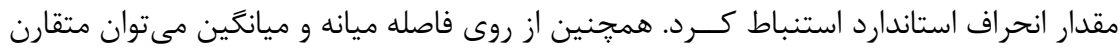

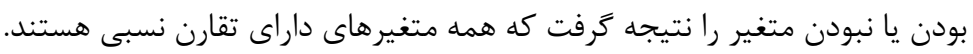

\begin{tabular}{|c|c|c|c|c|c|}
\hline ماكزيمم & مينيمم & انحراف معيار يزوهش & توصيفى م & لميانگين - امار & متغير \\
\hline 19.01 . & IT.rq. & $1.1 \% F$ & 10.99 . & $10.9 \wedge \mathrm{V}$ & خوانايى \\
\hline .49. & $\theta . r \mu$. &. $.1 \cdot 4$ &. .1. &. .91 & بازده دارايى \\
\hline $1 \ldots$ & $\because \cdots$ & . TEY & $\cdots$ & - . .99 & تغييرات حسابرس \\
\hline 4.91. & 1.91. & $.4 r$. & f.rv. & F.TDG & ناخير كزارش حسابرس \\
\hline 1.11 &. .4. &. .11 & .099. &. .090 & اهرم مالى \\
\hline$|V . \Delta|$. & $r . \Delta V$. & r... & $11 . r \cdot \Delta$ & 11.rVF & اندازه \\
\hline 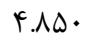 & r.r.. & • • & r.ఎ. & r.Y.q & عمر \\
\hline
\end{tabular}

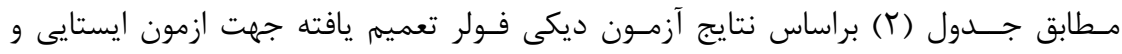

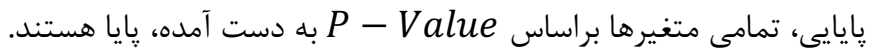
جدول r - نتايج آزمون ريشه واحد ديكى - فولر تعميم يافته باسنه

\begin{tabular}{|c|c|c|c|}
\hline نتيجه & $P-$ Value & آماره ADF & 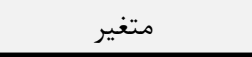 \\
\hline بدون روند و عرض از مبداء در سطح يايا است & 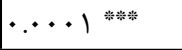 & DI9.1vQ & 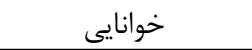 \\
\hline بدون روند و عرض از مبداء در سطح پايا است & 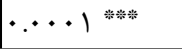 & $90 \cdot . \Delta 91$ & بازده دارايى \\
\hline بدون روند و عرض از مبداء در سطح پايا است & 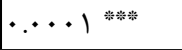 & $499.1 \mathrm{VF}$ & تغييرات حسابرس \\
\hline بدون روند و عرض از مبداء در سطح پايا است & 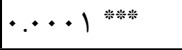 & Vq...91 & تاخير گزارش حسابرس \\
\hline با روند و با عرض از مبداء در سطح پايا است & 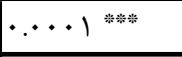 & $\Delta 99.1 \mathrm{VI}$ & 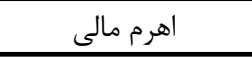 \\
\hline بدون روند و با عرض از مبداء در سطح يايا است & 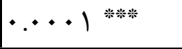 & $\Delta \Delta 9.9 F T$ & 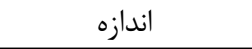 \\
\hline بدون روند و با عرض از مبداء در سطح پايا است & 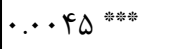 & $|\Lambda T .9| \mathrm{V}$ & 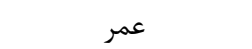 \\
\hline
\end{tabular}

 
دوفصلنامه حسابدارى ارزشى و رفتارى، سال شثم، شماره يازدهم، بهار و تابستان + +ع ا

\begin{tabular}{|c|c|}
\hline \multicolumn{2}{|c|}{ مدل اول( فرضيه اول) } \\
\hline$P-$ Value & آماره آزمون- جاو \\
\hline$\cdot \cdots 1^{\text {絭綡 }}$ & $9 . \Delta 11$ \\
\hline \multicolumn{2}{|c|}{ نتايج آزمون هاسمن } \\
\hline 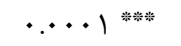 & $9 . \Delta 9 Y$ \\
\hline \multicolumn{2}{|c|}{ مدل دوم ( فرضيات دوم و سوم ) } \\
\hline$P-$ Value & آماره آزمون- جاو \\
\hline 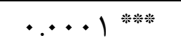 & r.TFA \\
\hline \multicolumn{2}{|c|}{ نتايج آزمون هاسمن } \\
\hline$\cdot \cdots 1^{\text {絭漛 }}$ & 9.994 \\
\hline
\end{tabular}

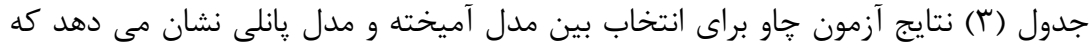

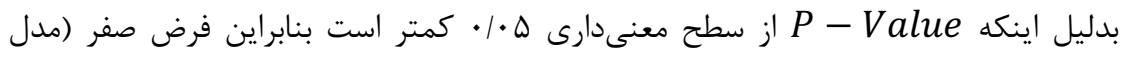

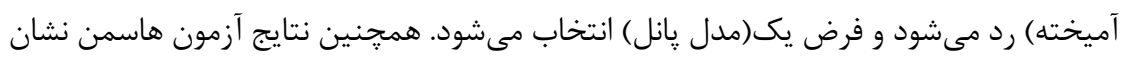

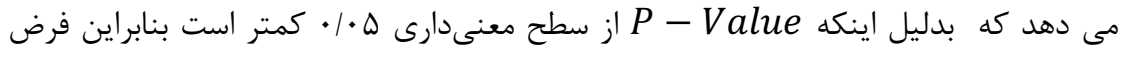

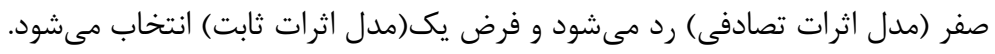

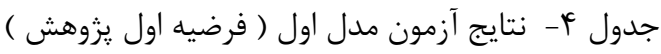

\begin{tabular}{|c|c|c|c|c|}
\hline \multicolumn{5}{|c|}{$R E A D A B I L I T Y=\beta_{0}+\beta_{1} R O A_{i t}+\beta_{2} S I Z E_{i t}+\beta_{3} A G E_{i t}+\beta_{4} L E V_{i t}+\varepsilon_{i t}$} \\
\hline$P-$ Value & آمار & انحراف معيار & 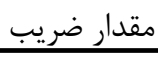 & متغير \\
\hline 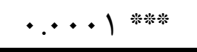 & $f . \Delta \cdot \Delta$ & - & $1 . F \wedge F$ & ثابت مدل \\
\hline 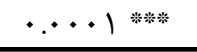 & 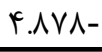 & - TVV & $1.149-$ & بازده دارايي \\
\hline . ITV & -.vq4- &. $.1 \mathrm{~F}$ & $\cdot .11-$ & اندازه \\
\hline$\cdot \Delta V r$ & - $\Delta S F$ & $\cdot \cdot V Y^{F}$ & $\because$ Er & عمر \\
\hline$\because \Delta 9$ & $1 . \wedge \wedge \Lambda-$ & $\cdot .19 \mathrm{~V}$ & $\cdot .19-$ & 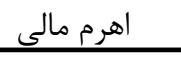 \\
\hline \multicolumn{2}{|c|}{$\cdot . t T$} & \multicolumn{3}{|c|}{ 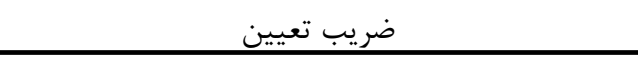 } \\
\hline \multicolumn{2}{|c|}{$\cdot .41$} & \multicolumn{3}{|c|}{ ضريب تعيين تعديل شده } \\
\hline \multicolumn{2}{|c|}{$(\cdot \cdot 1 * * * *) \quad r .91 \mathrm{~V}$} & \multicolumn{3}{|c|}{ 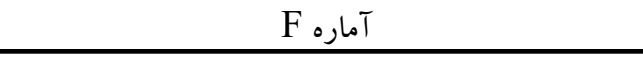 } \\
\hline
\end{tabular}


طبق جداول (\&) مدل ركرسيونى با توجه به آماره F و

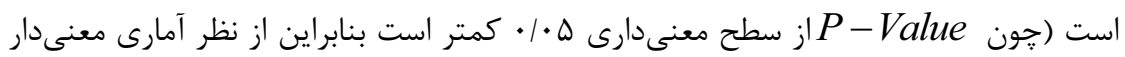

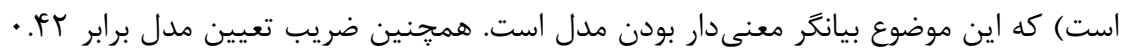

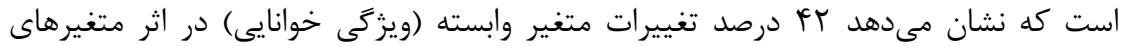

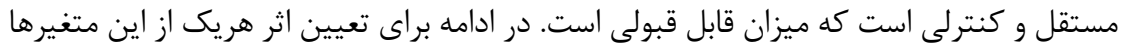

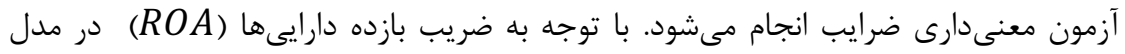

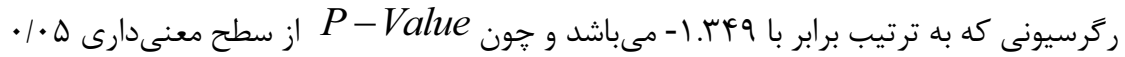
كمتر است. بنابراين از نظر آمارى معنىدار است و فرضيه اول إل رد نمى برى شود يعنى: ميزان بازده

$$
\text { دارايى بر خوانايى زَارشهاى مالى تاثير منفى و معنى دارى دارئ دارد. }
$$

جدول ه- نتايج آزمون مدل دوم ( فرضيه هاى دوم و سوم )

\begin{tabular}{|c|c|c|c|c|}
\hline \multicolumn{5}{|c|}{$R E A D A B I L I T Y=\beta_{0}+\beta_{1} \mathrm{ARL}_{i t}+\beta_{2} \mathrm{AC}_{i t}+\beta_{3} \operatorname{SIZE}_{i t}+\beta_{4} A G E_{i t}+\beta_{5} L E V_{i t}+\varepsilon_{i t}$} \\
\hline$P-$ Value & آماره t & انحراف معيار & مقدار ضريب & متغير \\
\hline$\cdot \cdots 1$ & F.AT. & $\cdot . r q \vee$ & 1.910 & ثابت مدل \\
\hline$\cdot \cdots 1$ & $\Delta . q \mu$. & $\cdot .9 r$ & $\cdot . r 4 \Lambda$ & تاخير ززارش حسابرس \\
\hline$\cdot \cdots 1$ & -0.991 & $\because \cdot 9$. & $-\cdot \cdot r q 1$ & تغييرات حسابرس \\
\hline$\cdot V Y G$ & $-\cdot . r \Delta l$ & $\cdot$. & $-\cdot \cdot \Delta$ & 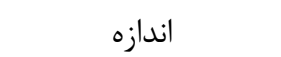 \\
\hline$\cdot .91 \cdot$ & r & .99 & $\because \cdots \wedge$ & عمر \\
\hline$\cdot .11 \cdot$ & $-1.9 \cdot r$ & $\cdot .1 \Delta 0$ &.$- t Y \wedge$ & اهرم مالى \\
\hline \multicolumn{2}{|c|}{ ع r. • } & \multicolumn{3}{|c|}{ ضريب تعيين } \\
\hline \multicolumn{2}{|c|}{$\cdot r \Delta$} & \multicolumn{3}{|c|}{ ضريب تعيين تعديل شده } \\
\hline$(\cdot \cdots+)^{\text {䄅䄅 }}$ & $r \cdot \Lambda T \cdot$ & \multicolumn{3}{|c|}{ F آماره F } \\
\hline
\end{tabular}

طبق جداول شماره (ه) ، مدل ركرسيونى با توجه به آماره Falue

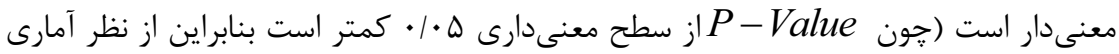

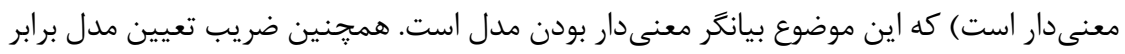

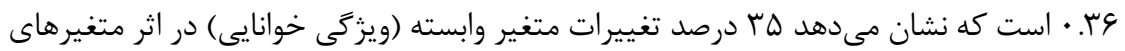


مستقل و كنترلى است كه ميزان قابل قبولى است. در ادامه براى تعيين اثر هريك از اين متغيرها در ادامه آزمون معنى دارى ضرايب انجام مى شود.

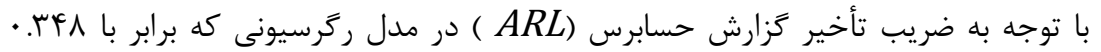

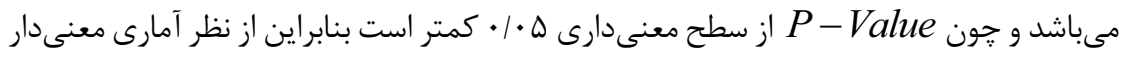

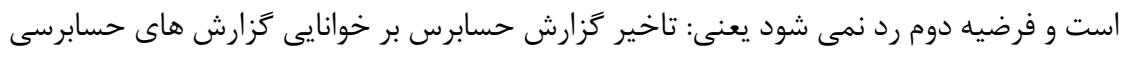
تاثير مثبت و معنى دارى دارد. با توجه به ضريب تغييرات حسابرس (AC) در مدل ركرسيونى كه برابر با اعبه. •--مىباشد و

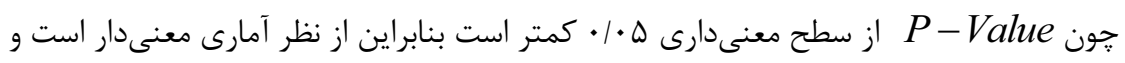

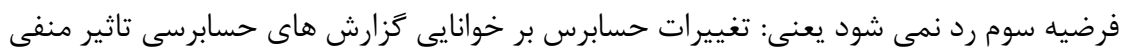

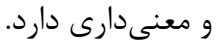

\section{9-نتيجه كيرى و بحث}

تقاضا براى حسابدارى و اطلاعات مالى نياز به درك بهتر انكيزه بِيرامون تهيه اين اسناد دارد.

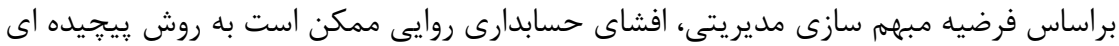

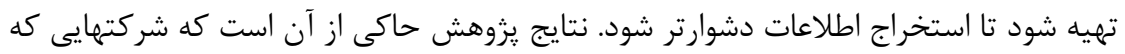

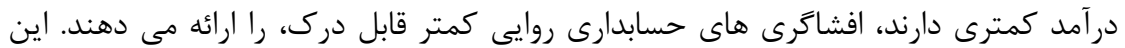

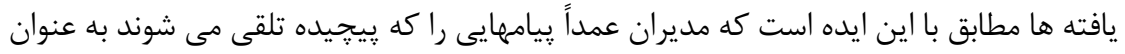

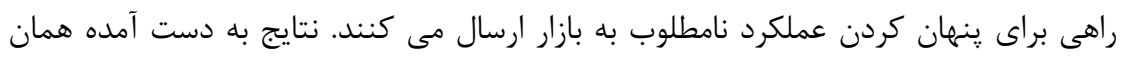

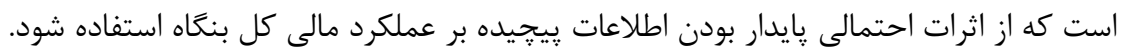

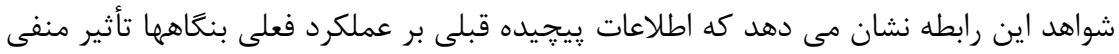

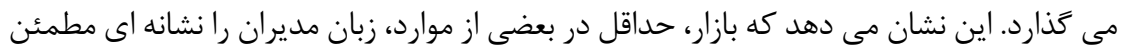

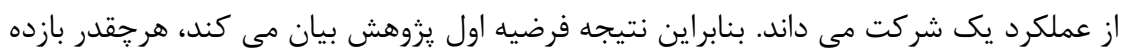

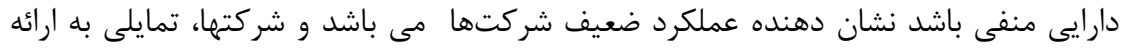

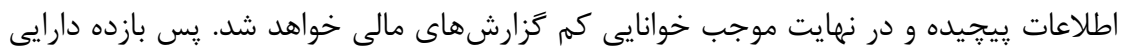

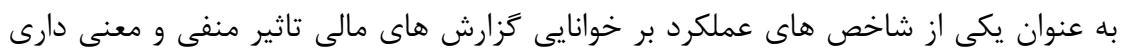

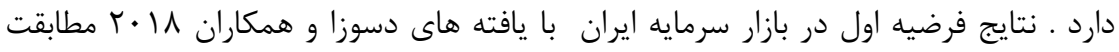

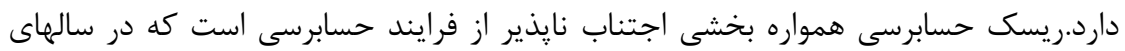

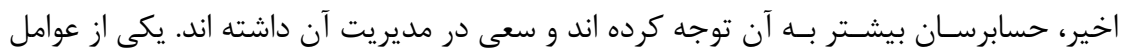

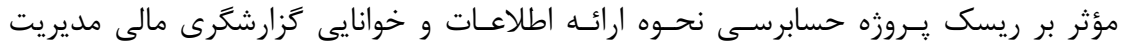

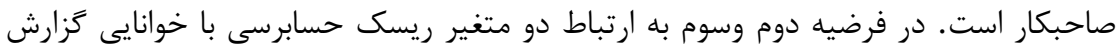


هاى حسابرسى يرداخته شد. معيارهاى ريسك يروزه حسابرسى يرداخته شده است. نتايج يزوهش

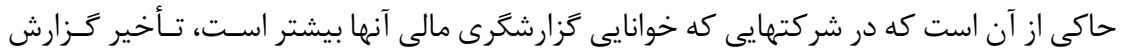

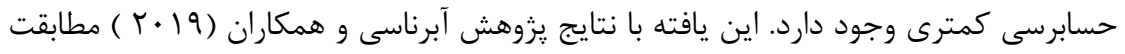

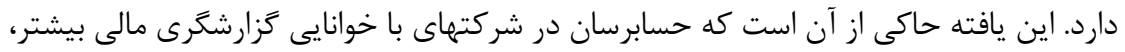

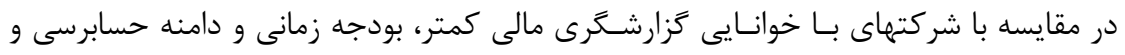

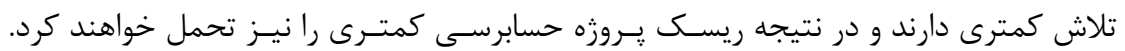

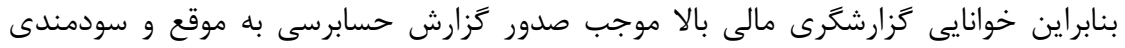

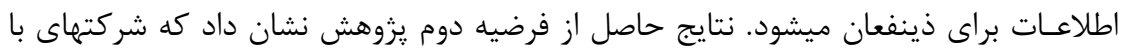

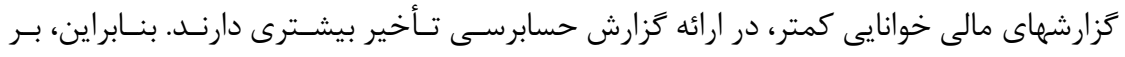

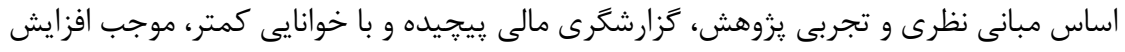

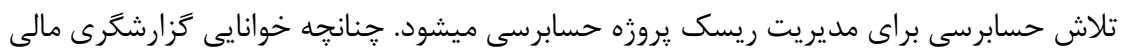

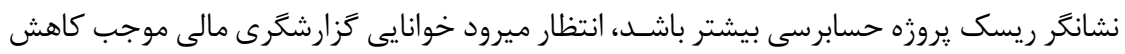

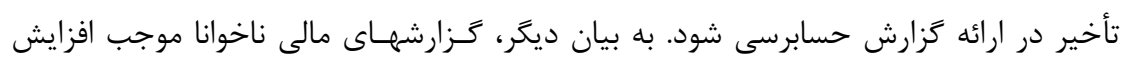

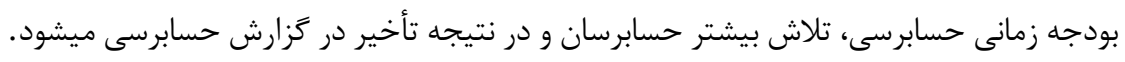

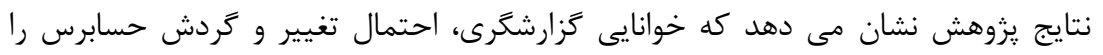

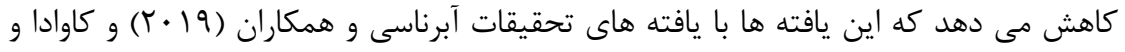

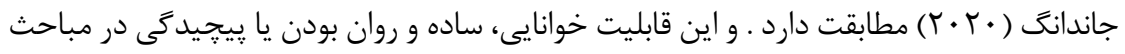

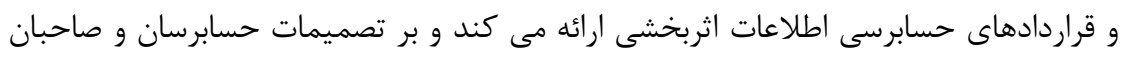
كار اثر مى كذارد .

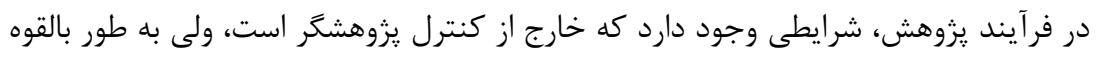

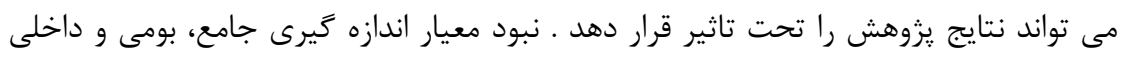

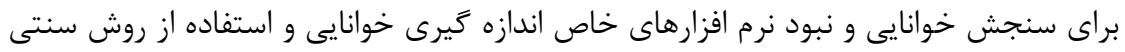
و دستى. همجنين تفاوت در روشهاى محاسبه متغيرهاى تحقيق در نتايج تحقيق تاثير داشته

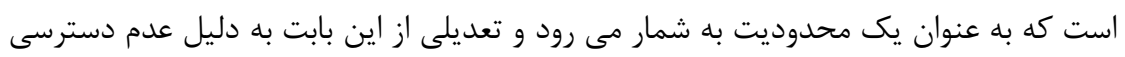
به اطلاعات صورت نكرفته است.

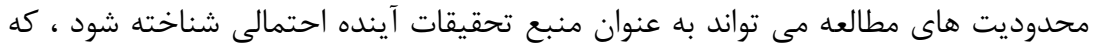

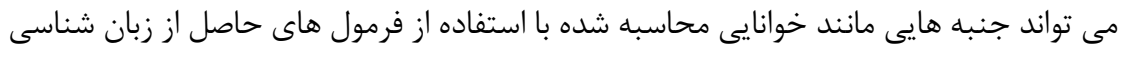

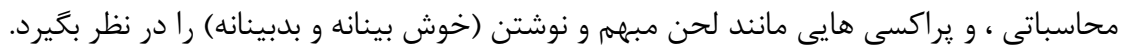

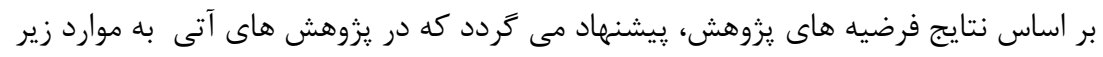


ا- در بررسى خوانايى ززارشهاى مالى و عملكرد شركتها، از شاخص هاى غير مالى عملكرد، در

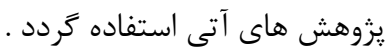

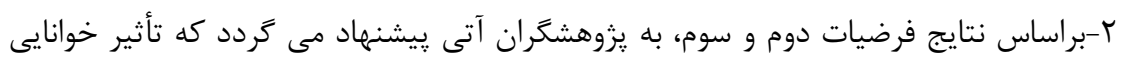

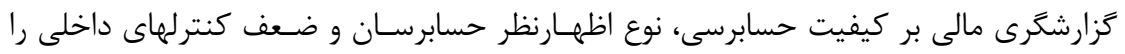
بررسى و آزمون كنند.

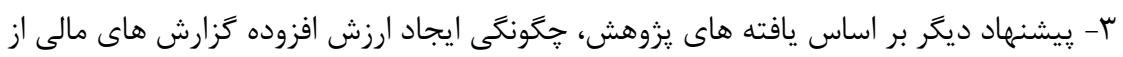

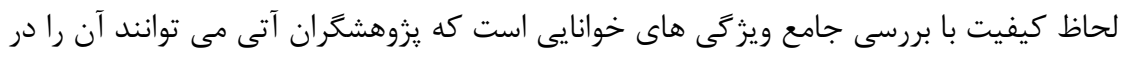

$$
\text { نظر بخيرند . }
$$

\section{V- تقدير ، تشكر و ملاحظات اخلاقى}

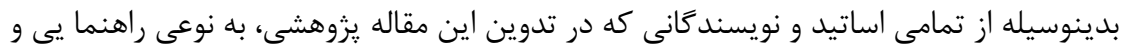
مشاوره نموده اند نهايت سياس و قدردانى را دارئم.

$$
\begin{aligned}
& \text { فهرست منابع }
\end{aligned}
$$

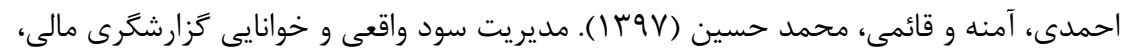

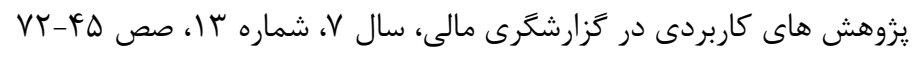

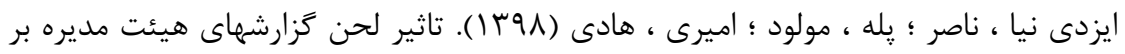

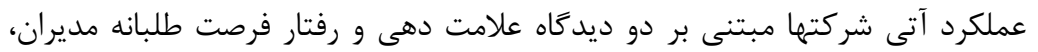

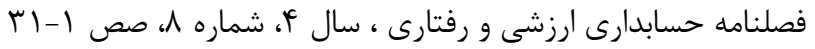

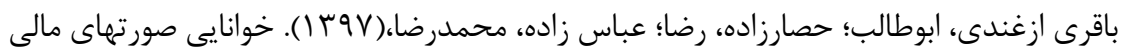

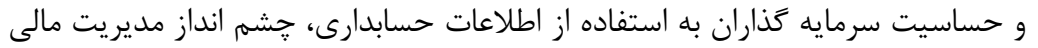

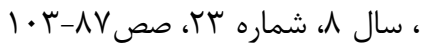

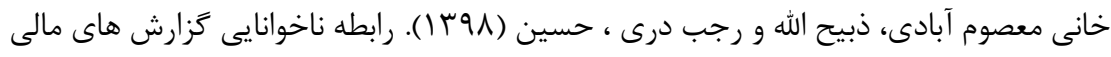

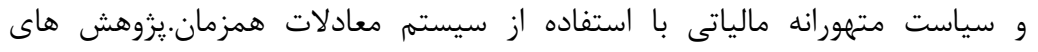

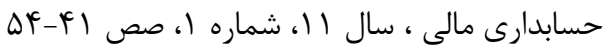

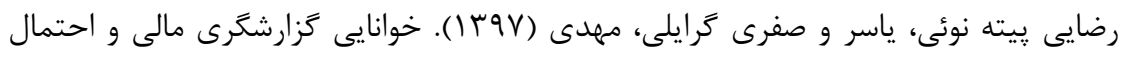

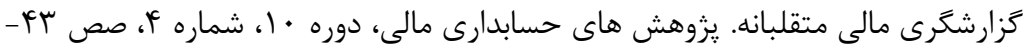




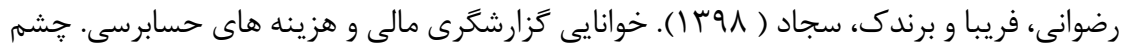

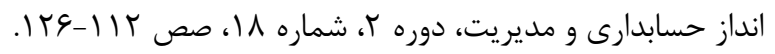

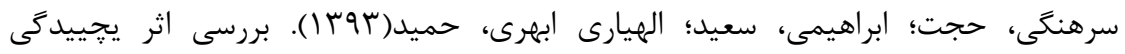

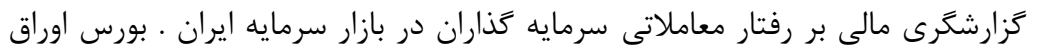

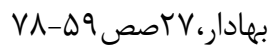

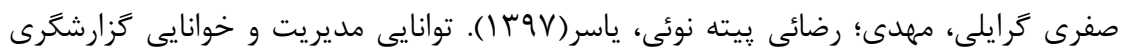

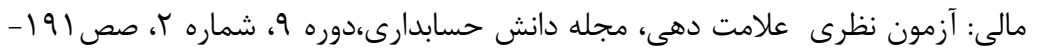

$$
\begin{aligned}
& \text { rIN }
\end{aligned}
$$

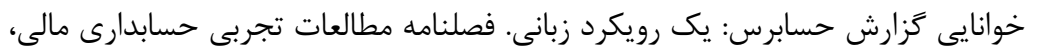

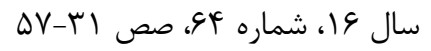

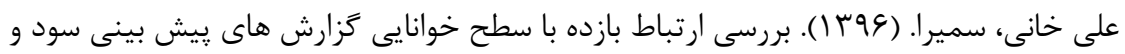

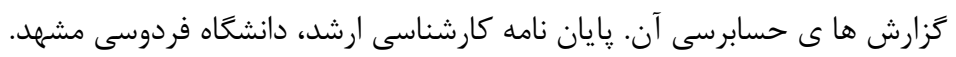

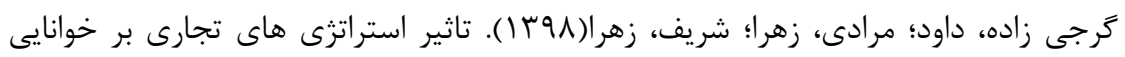

$$
\begin{aligned}
& \text { صورت }
\end{aligned}
$$

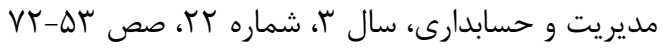

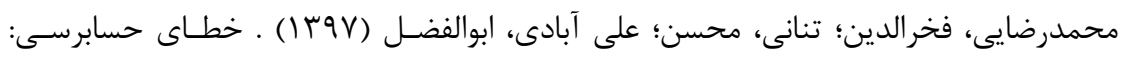

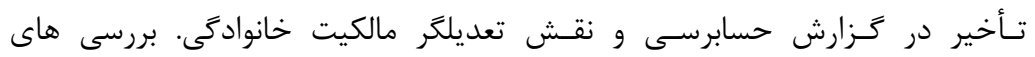

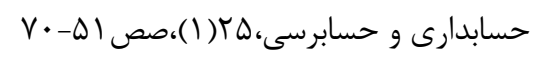

Ajina, A., Laouiti, M., \& Msolli, B. 2016. Guiding through the Fog: Does annual report readability reveal earnings management? Research in International Business and Finance, 38: 509-516.

Abernathy,J.L.,Guo, F., Kubik, T.R. \& Masli, A.2018. Financial statement footnote readability and corporate audit outcomes. Auditing: A Journal of Practice and Theory,38(2) : 1-26

Asay, H.S., Libby, R. \& Rennekamo, K. 2018. Firm performance, reporting goals, and language choices in narrative disclosures. Journal of Accounting and Economics, 65(2-3): p 380-398,

Ashton, R.H., Willingham, J.J., \& Elliott, R.K. 1987. An empirical analysis of audit delay. Journal of Accounting Research, 25(2), 275-292

Aymen 'A. 'B.S. Sourour 'and M. Badreddine. 2018. The effect of annual report readability on financial analysts' behavior. Journal of Economics, Finance and Accounting 5(1): 26-37.

Bloomfield, R. 2002. The "Incomplete Revelation Hypothesis" and Financial Reporting. Accounting Horizons, 16(3) : 233-243. 
Boubaker,S, D, Gounopoulos, and H, Rjiba. 2019, Annual report readability and stock liquidity. Financial Markets, Institutions and Instruments 28(2): 159-186

Chun, C., Hui, K \& Zhang, Y. 2016. "Analyst Report Readability and Stock Returns". Available at SSRN2182422.

Courtis, J. K. 1987. Fry, Smog, Lix and Rix: Insinuations About Corporate Business Communications. JThe Journal of Business Communication, 24(2): 19-27.

Davis, A. K., Piger, J. M., \& Sedor, L. M. 2012. Beyond the Numbers: Measuring the Information Content of Earnings Press Release Language. Contemporary Accounting Research, 29(3), 845-868.

Dempsey,S.J ., Harrison,D.M., Luchtenberg,K.F.,\& Seiler,M.J. 2010. Financial Opacity and Firm Performance: The Readability of REIT Annual Reports.Springer Scince + Business Media, LLC 2010.

DeFond, M. L., Chee, Y. L. \& Zaang, Y. 2016. Client Conservatism and AuditorClient Contracting. The Accounting Review, 90(1), 69-98

De Souza, J.A.S., Rissatti, J.C., Rover, S. \& Borba, J.A. 2019. The linguistic complexities of narrative accounting disclosure on financial statements: An analysis based on readability characteristics. Research in International Business and Finance, 48: 59-74,

DuBay, W. H. 2004. The principles of readability. Impact Information. https://doi.org/10.1.1.91.4042

Fakhfakh, Mondher.2015. The readability of international illustration of auditor's report: An advanced reflection on the compromise between normative principles and linguistic requirements. Journal of Economics, Finance and Administrative Science, 20

Fisher, R,, Van Staden, C. \& Richards, G. 2019. Watch that tone: An investigation of the use and stylistic consequences of tone in corporate accountability disclosures. Accounting, Auditing \& Accountability Journal, 35(1): p 77-105.

Hasan, M.M. 2017. Managerial ability, annual report readability and disclosure tone (April 23, 2017).

Hillegeist, S. A. 1999. Financial reporting and auditing under alternative damage appointment rules. The Accounting Review, 74(3), 347-369.

Hung, Y.S. \& Cheng, Y.C. 2018. The impact of information complexity on audit failures from corporate fraud: Individual auditor level analysis. Asia Pacific Management Review 23 2018: 72-85.

Jones, M. J. 1988. A Longitudinal Study of the Readability of the Chairman's Narratives in the Corporate Reports of a UK Company. Accounting and Business Research, 18(72), 297-305.

Jones, M. J., \& Shoemaker, P. A. 1994. Accounting narratives: a review of empirical studies of content and readability. Journal of Accounting Literature, 13, 142184.

Kim, Y. \& Park, M. S. 2014. Real activities manipulation and auditors' client-retention decisions. The Accounting Review, 89(1), 367-401.

Knechel, W. R., \& Payne, J. L. 2001. Additional evidence on audit report lag. Auditing: A Journal of Practice \& Theory, 20(1), 137-146.

Lee, T. A., \& Tweedie, D. P. 1975. Accounting information: an investigation of private shareholder usage. Accounting and Business Research, 5(20): 280-291 
Leffa, V. J. 1996. Fatores da compreensão na leitura. Cadernos Do IL, 15(15): 143159.

Li, F. 2008. Annual report readability, current earnings, and earnings persistence. Journal of Accounting and Economics, 45(2-3): 221-247.

Lo, K., Ramos, F., \& Rogo, R. 2017. Earnings management and annual report readability. Journal of Accounting and Economics, 63(1):1-25.

Lobo, G.J., \& Zhao, Y. 2013. Relation between audit effort and financial report misstatements: Evidence from quarterly and annual restatements. The Accounting Review, 88(4), 1385-1412

Miller, B. P. 2010. The effects of reporting complexity on small and large investor trading. The Accounting Review, 85(6), 2107-2143.

Pound, G. D. 1981. "A note on audit report readability", Accounting and Finance, 21, 1.

Previts, G. J., Bricker, R. J., Robinson, T. R. \& Young, S. J. 1994. A content analysis of sellside financial analysts company reports. Accounting Horizons, 8(2), 5570.

Schroeder, N., \& Gibson, C. G. 1990. Readability of Management's Discussion and Analysis. Accounting Horizons, 4(4), 78-87.

Shu, S. Z. 2000. Auditor resignations: Clientele effects and legal liability. Journal of Accounting and Economics, 29(2), 173-205.

Simunic, D. A., \& Stein, M. T. 1987. The Impact of Litigation Risk on Audit Pricing: A Review of the Economics and the Evidence. Auditing: A Journal of Practice \& Theory, 15, 120-134

Smith, M., \& Taffler, R. 1992. Readability and Understandability: Different Measures of the Textual Complexity of Accounting Narrative. Accounting, Auditing \& Accountability Journal, 5(4): 84-98..

Shu, S. Z. 2000. Auditor resignations: Clientele effects and legal liability. Journal of Accounting and Economics, 29(2), 173-205.

You, H., and X. Zhang. 2009. Financial reporting complexity and investor underreaction to 10-K information. Review of Accounting Studies 14 (4): 559586 